December 2001 • NREL/TP-510-31351

\title{
Technoeconomic Analysis of the Thermocatalytic Decomposition of Natural Gas
}

\author{
Janice M. Lane \\ Pamela L. Spath
}

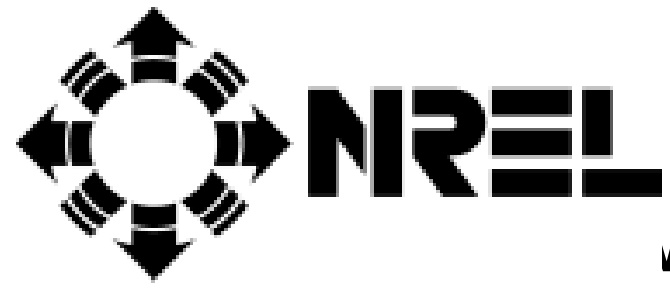

wable Energy Laboratory

1617 Cole Boulevard

Golden, Colorado 80401-3393

NREL is a U.S. Department of Energy Laboratory

Operated by Midwest Research Institute • Battelle • Bechtel

Contract No. DE-AC36-99-G010337 


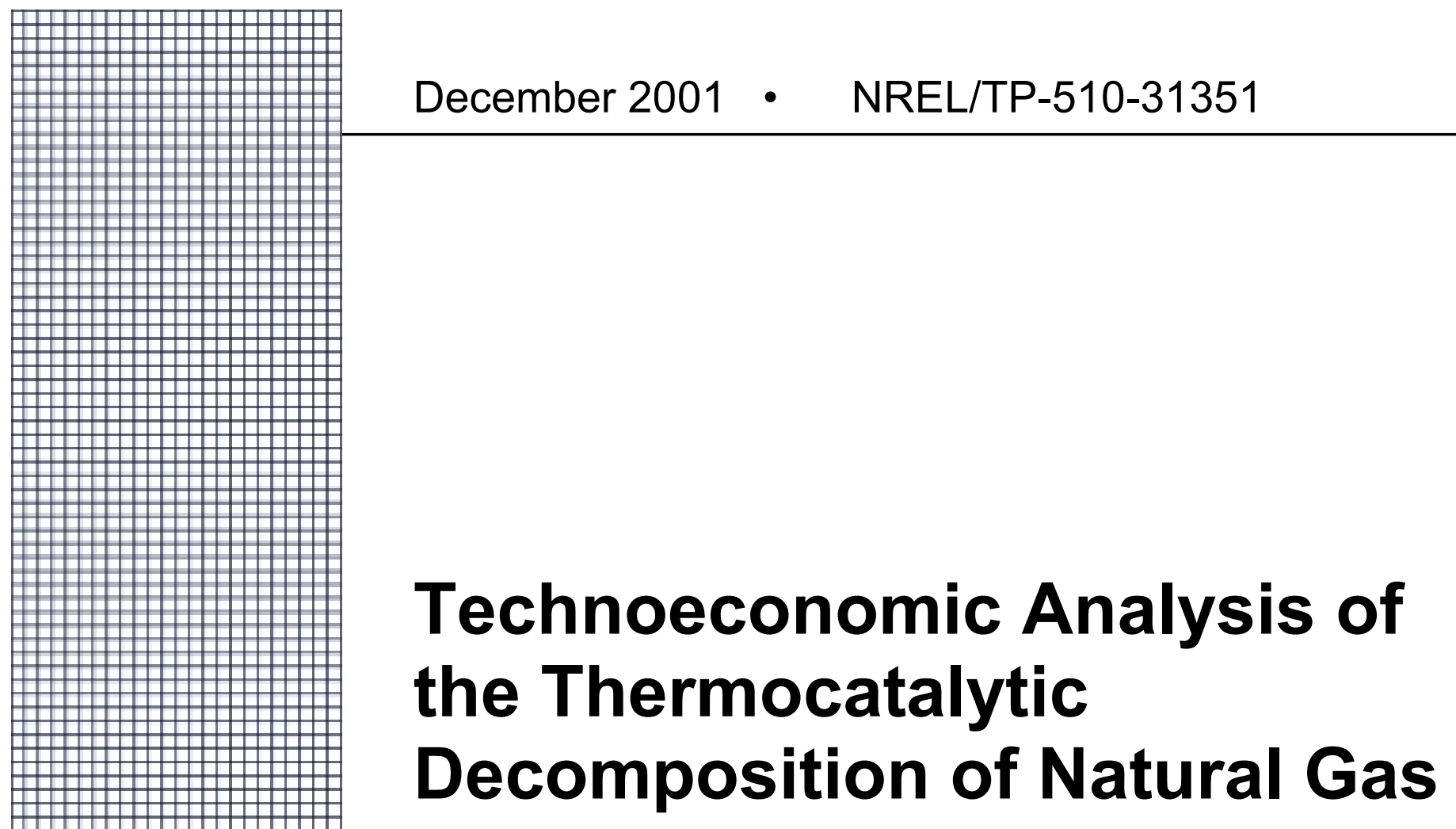

Janice M. Lane
Pamela L. Spath

Prepared under Task No. HY024041

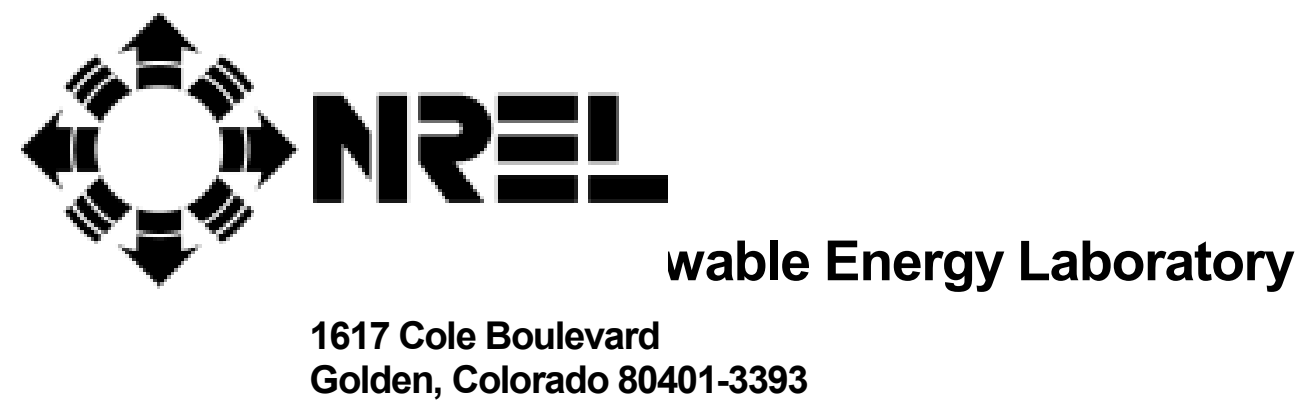

NREL is a U.S. Department of Energy Laboratory

Operated by Midwest Research Institute • Battelle • Bechtel

Contract No. DE-AC36-99-G010337 


\section{NOTICE}

This report was prepared as an account of work sponsored by an agency of the United States government. Neither the United States government nor any agency thereof, nor any of their employees, makes any warranty, express or implied, or assumes any legal liability or responsibility for the accuracy, completeness, or usefulness of any information, apparatus, product, or process disclosed, or represents that its use would not infringe privately owned rights. Reference herein to any specific commercial product, process, or service by trade name, trademark, manufacturer, or otherwise does not necessarily constitute or imply its endorsement, recommendation, or favoring by the United States government or any agency thereof. The views and opinions of authors expressed herein do not necessarily state or reflect those of the United States government or any agency thereof.

Available electronically at http://www.osti.gov/bridge

Available for a processing fee to U.S. Department of Energy

and its contractors, in paper, from:

U.S. Department of Energy

Office of Scientific and Technical Information

P.O. Box 62

Oak Ridge, TN 37831-0062

phone: 865.576.8401

fax: 865.576 .5728

email: reports@adonis.osti.gov

Available for sale to the public, in paper, from:

U.S. Department of Commerce

National Technical Information Service

5285 Port Royal Road

Springfield, VA 22161

phone: 800.553.6847

fax: 703.605.6900

email: orders@ntis.fedworld.gov

online ordering: http://www.ntis.gov/ordering.htm 


\section{Executive Summary}

Hydrogen production via thermocatalytic decomposition of natural gas reduces carbon dioxide emissions per kilogram of hydrogen produced, when compared to steam methane reforming (SMR). Research for this process is being conducted by Dr. Nazim Muradov of the Florida Solar Energy Center (FSEC). The National Renewable Energy Laboratory (NREL) performed an economic analysis, examining two process designs for producing hydrogen from thermocatalytic decomposition based on Dr. Muradov's research. The first design uses partial oxidation of some of the natural gas and carbon within the reactor to produce heat for the decomposition reaction. The second design combusts natural gas in a separate vessel to heat carbon that is recycled back to the reactor. Both methods use pressure swing adsorption (PSA) to purify the product hydrogen, then the PSA offgas is recycled to the reactor to improve hydrogen production efficiency. A pure carbon byproduct, free of sulfur and ash impurities, is assumed to be sold.

Due to the recent volatility in natural gas costs, a relationship was developed between hydrogen selling price and natural gas cost. Depending on the size of the plant and natural gas cost, the results of the economic analysis show a predicted plant gate hydrogen selling price of $\$ 11-\$ 31 / \mathrm{GJ}$ for the partial oxidation base case and $\$ 7-\$ 21 / \mathrm{GJ}$ for the three vessel system base case. The base case assumes a carbon byproduct selling price of $\$ 0.30 / \mathrm{kg}$ and a $15 \%$ after-tax internal rate of return (IRR). The following three plant sizes were evaluated: $0.16,0.53$, and $1.58 \mathrm{Nm}^{3} /$ day $(6,20$, and 60 MMscfd) of hydrogen with the largest plant size having the lowest hydrogen selling price.

Hydrogen storage and transportation contribute an additional $\$ 0.1-\$ 13 / G J$ to the hydrogen selling price with the least expensive option being no storage and pipeline transportation and the most expensive option being liquid hydrogen storage and liquid rail transportation. Results from the sensitivity analysis determined the contribution of 25 assumption variables to uncertainty in the hydrogen selling price. The variables were changed within the risk assessment software, Crystal $\mathrm{Ball}^{\circledR}$, and those variables that have the greatest influence on the hydrogen selling price are yield of carbon, hydrogen production factor, operating capacity factor, and carbon selling price.

Although the carbon selling price was an assumption variable in Crystal Ball ${ }^{\circledR}$, it was also varied independently of the other assumption variables to determine the dependence of the hydrogen selling price on the carbon selling price alone. If the carbon cannot be sold as a byproduct, the hydrogen selling price increases by $\$ 8 / \mathrm{GJ}$ from the base case in the partial oxidation system and by $\$ 5 / \mathrm{GJ}$ in the three vessel system. Although the base case assumes a $15 \%$ after-tax IRR, the sensitivity of the hydrogen selling price to rates of $0 \%$ pre-tax, $10 \%$ after-tax, and $20 \%$ after-tax IRR were investigated. IRR has a large effect on the hydrogen selling price. A five percentage points increase in IRR from the base case results in a $28 \%$ increase in the hydrogen selling price for the partial oxidation system and a $21 \%$ increase for the three vessel system. A five percentage points decrease in IRR leads to a $25 \%$ decrease in the partial oxidation system and a $17 \%$ decrease in the three vessel system.

Both systems were modeled in ASPEN Plus ${ }^{\circledR}$ to determine the energy and material balance. The greenhouse gas emissions $\left(\mathrm{CO}_{2}, \mathrm{CH}_{4}\right.$, and $\left.\mathrm{N}_{2} \mathrm{O}\right)$ were then compared to those for hydrogen production via SMR. A typical SMR plant produces $8.9 \mathrm{~kg} \mathrm{CO}_{2}$-eq. $/ \mathrm{kg}$ hydrogen produced (Spath and Mann 2000). The greenhouse gas emissions emitted from the partial oxidation and three vessel systems are $46 \%$ and $26 \%$ lower than the SMR system per kilogram of hydrogen produced. However, these emissions are solely from the production plant itself. To accurately compare the greenhouse gas emissions from these two process with those from SMR, a life-cycle approach was taken and emissions from the hydrogen production plant, upstream natural gas production and 
distribution, and avoided carbon black production were included. Emissions from these three sources result in a 59\% reduction for the partial oxidation system from SMR and a 33\% reduction for the three vessel system. Although this economic analysis does not include carbon credits in the hydrogen selling price, the hydrogen selling price would be reduced if a carbon credit for avoided $\mathrm{CO}_{2}$ emissions were applied. Results of the sensitivity analysis yielded several research recommendations. Current data from Dr. Muradov are based on a single pass reactor setup. Experimental trials with a carbon recycle to the reactor will give a better understanding of how the carbon activity changes over time. Also, the carbon selling price has a large influence on the hydrogen selling price, so in-depth testing of the carbon quality will allow a more accurate determination of the carbon selling price. 


\section{Table of Contents}

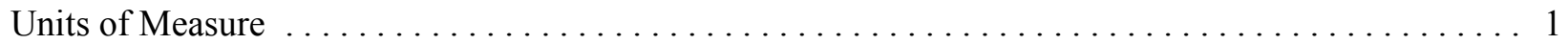

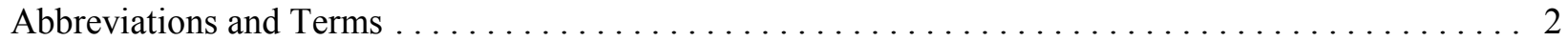

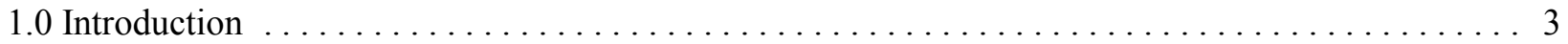

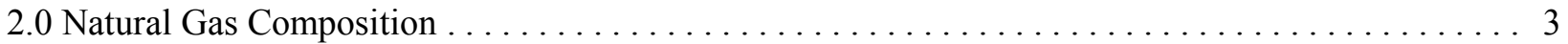

3.0 Process Descriptions for Hydrogen from Thermocatalytic Decomposition $\ldots \ldots \ldots \ldots \ldots \ldots . .3$

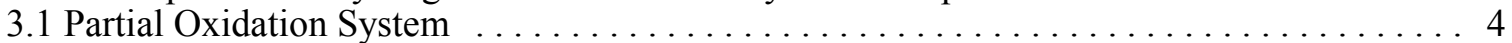

3.2 Three Vessel System . . . . . . . . . . . . . . . . . . . . . . . 7

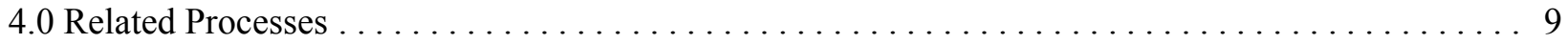

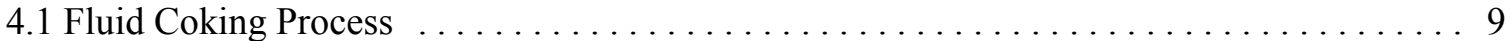

4.2 Carbon Black Process ... . . . . . . . . . . . . . . . . . . . . . . . . . . . 9

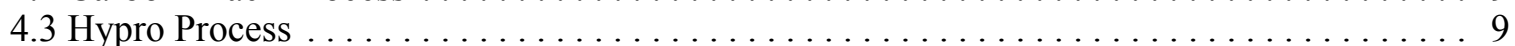

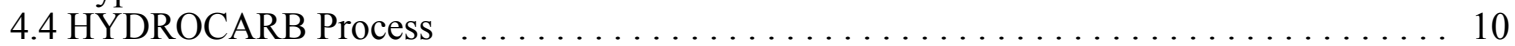

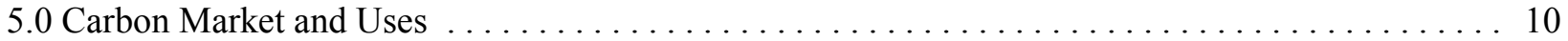

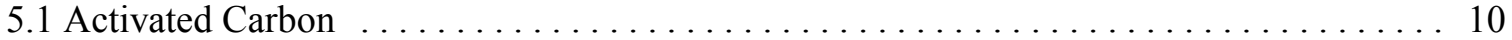

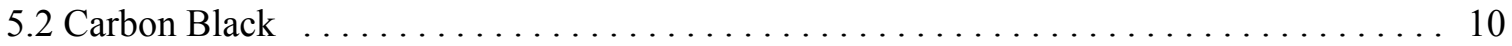

5.3 Graphitic Carbon . . . . . . . . . . . . . . . . . . . . . . . . . 10

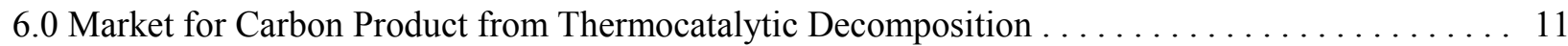

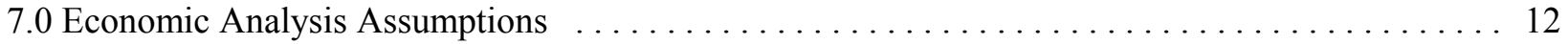

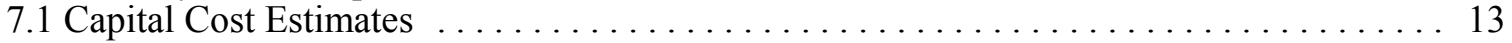

7.2 Natural Gas Cost . . . . . . . . . . . . . . . . . . . . . . . . . 13

7.3 Membrane for Hydrogen Purification $\ldots \ldots \ldots \ldots \ldots \ldots \ldots \ldots \ldots \ldots \ldots \ldots \ldots \ldots \ldots \ldots \ldots \ldots \ldots \ldots$

8.0 Sensitivity Analysis Using Crystal Ball ${ }^{\circledR} \ldots \ldots \ldots \ldots \ldots \ldots \ldots \ldots \ldots \ldots \ldots \ldots$

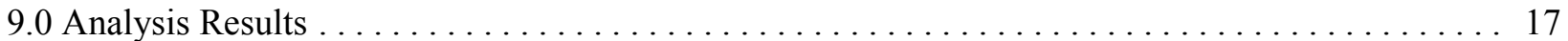

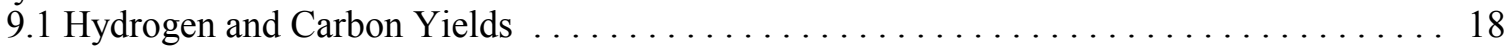

9.2 Capital Costs . . . . . . . . . . . . . . . . . . . . . . . . . . . . 18

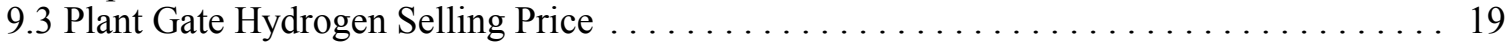

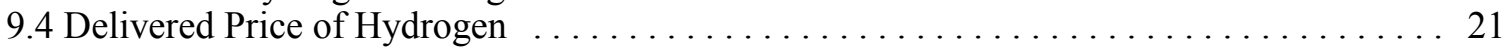

9.5 Sensitivity Analysis Results . . . . . . . . . . . . . . . . . . . . . . . . . . . . . 22

9.5.1 Monte Carlo Results . . . . . . . . . . . . . . . . . . . . . . . . . . . 22

9.5.2 Sensitivity of Hydrogen Selling Price to Carbon Selling Price . . . . . . . . . 22

9.5.3 Sensitivity of Hydrogen Selling Price to Internal Rate of Return . . . . . . . . 23

9.5.4 Sensitivity Analysis Results of Adding Compression and a Membrane . . . . . . 25

9.6 Greenhouse Gas Emissions . . . . . . . . . . . . . . . . . . . . . . . . 25

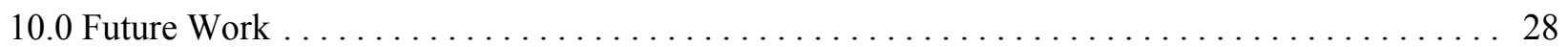

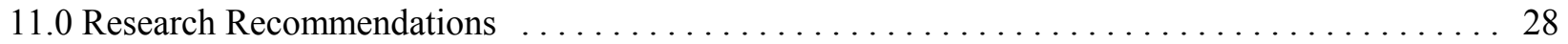

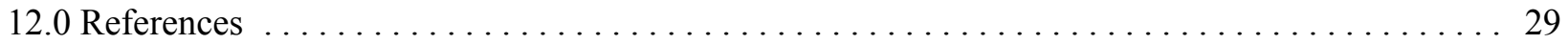




\section{List of Tables}

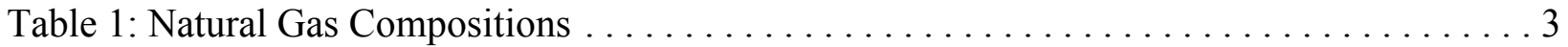

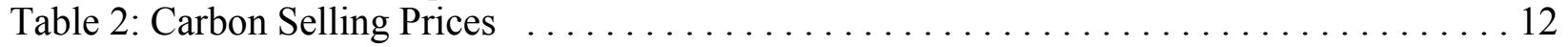

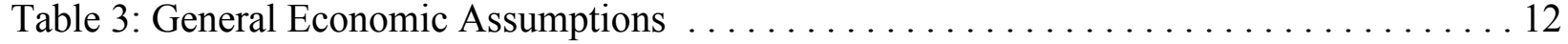

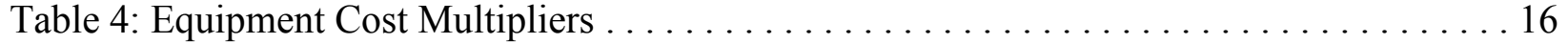

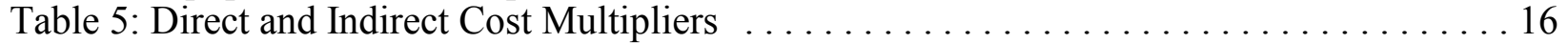

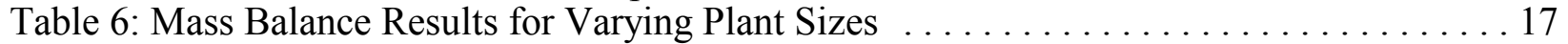

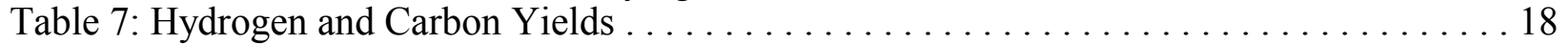

Table 8: Total Fixed Capital Investment . . . . . . . . . . . . . . . . . . . . . . . 19

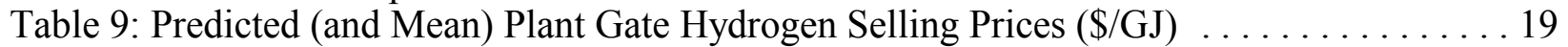

Table 10: Hydrogen Storage and Transport Scenarios . . . . . . . . . . . . . . . . . 21

Table 11: Additional Costs of Hydrogen Storage and Transportation for Each Option . . . . . 22

Table 12: Sensitivity of Plant Gate Hydrogen Selling Price to Carbon Selling Price . . . . . . . 23

Table 13: Plant Gate Hydrogen Selling Prices for Differing Internal Rates of Return . . . . . . 23

Table 14: Base Case with a Membrane and/or a Natural Gas Compressor . . . . . . . . . . . 25

\section{List of Figures}

Figure 1: Process Flowsheet for Thermocatalytic Decomposition of Natural Gas via Partial

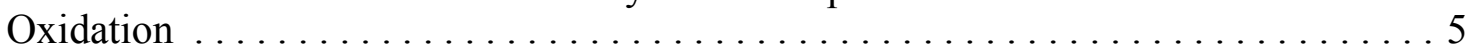

Figure 2: Thermal Decomposition of Methane Equilibrium Curve $\ldots \ldots \ldots \ldots \ldots \ldots \ldots$

Figure 3: Process Flowsheet for Thermocatalytic Decomposition of Natural Gas using Three

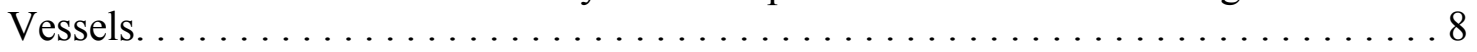

Figure 4: Hydrogen Selling Price versus Natural Gas Cost (15\% after-tax IRR) . . . . . . . 20

Figure 5: Hydrogen Selling Price versus Carbon Selling Price (15\% after-tax IRR) . . . . . . . 24

Figure 6: Greenhouse Gas Emissions from Hydrogen Production via Steam Methane Reforming and Thermocatalytic Decomposition of Natural Gas $\ldots \ldots \ldots \ldots \ldots \ldots \ldots$ 


\section{Units of Measure}

Metric units of measure are used in this report. Therefore, material consumption is reported in units based on the gram (e.g., kilogram or megagram), energy consumption based on the joule (e.g., kilojoule or megajoule), and distance based on the meter (e.g., kilometer). When it can contribute to the understanding of the analysis, the English system equivalent is stated in parentheses. The metric units used for each parameter are given below, with the corresponding conversion to English units.

Mass: $\quad$ kilogram $(\mathrm{kg})=2.205$ pounds

$$
\text { megagram }(\mathrm{Mg})=\text { metric tonne }(\mathrm{T})=1 \times 10^{6} \mathrm{~g}=1.102 \text { ton }(\mathrm{t})
$$

Distance: $\quad$ kilometer $(\mathrm{km})=0.62$ mile $=3,281$ feet

Area: $\quad$ hectare $(\mathrm{ha})=10,000 \mathrm{~m}^{2}=2.47$ acres

Volume: $\quad$ cubic meter $\left(\mathrm{m}^{3}\right)=264.17$ gallons normal cubic meters $\left(\mathrm{Nm}^{3}\right)=0.02628$ standard cubic feet $(\mathrm{scf})$ at a standard temperature and pressure of $15.6^{\circ} \mathrm{C}\left(60^{\circ} \mathrm{F}\right)$ and $101.4 \mathrm{kPa}(14.7 \mathrm{psi})$, respectively

Pressure: $\quad$ kilopascals $(\mathrm{kPa})=0.145$ pounds per square inch

Energy: $\quad$ kilojoule $(\mathrm{kJ})=1,000$ Joules $(\mathrm{J})=0.9488 \mathrm{Btu}$ gigajoule $(\mathrm{GJ})=0.9488 \mathrm{MMBtu}($ million Btu)

kilowatt-hour $(\mathrm{kWh})=3,414.7 \mathrm{Btu}$

gigawatt-hour $(\mathrm{GWh})=3.4 \times 10^{9} \mathrm{Btu}$

Power: megawatt $(\mathrm{MW})=1 \times 10^{6} \mathrm{~J} / \mathrm{s}$

Temperature: ${ }^{\circ} \mathrm{C}=\left({ }^{\circ} \mathrm{F}-32\right) / 1.8$

\section{Hydrogen Equivalents:}

$$
\begin{aligned}
1 \mathrm{~kg} \mathrm{H} 2 & =423.3 \mathrm{scf} \text { gas }=11.126 \mathrm{Nm}^{3} \text { gas } \\
& =142 \mathrm{MJ}(\mathrm{HHV} \text { basis })=120 \mathrm{MJ}(\text { LHV basis })
\end{aligned}
$$




\section{Abbreviations and Terms}

Btu -

British thermal units

$\mathrm{CO}_{2}$-equivalence

Expression of the GWP in terms of $\mathrm{CO}_{2}$ for the following three components $\mathrm{CO}_{2}, \mathrm{CH}_{4}, \mathrm{~N}_{2} \mathrm{O}$, based on Intergovernmental Panel on Climate Change weighting factors

DCFROR- $\quad$ Discounted Cash Flow Rate of Return

DEAM - $\quad$ Data for Environmental Analysis and Management (also referred to as the TEAM $^{\circledR}$ database)

EIA -

Energy Information Administration

FSEC - $\quad$ Florida Solar Energy Center

GWP - global warming potential

HHV - $\quad$ higher heating value

IRR - internal rate of return

kWh -

kilowatt-hour (denotes energy)

LHV -

lower heating value

MMSFCD - $\quad$ million standard cubic feet per day

$\mathrm{N}_{2} \mathrm{O}-$

$\mathrm{Nm}^{3}-$

nitrous oxide

normal cubic meters

NREL -

PSA -

National Renewable Energy Laboratory

SMR -

pressure swing adsorption

steam methane reforming

TCD -

thermocatalytic decomposition

$\mathrm{TEAM}^{\circledR}$ -

U.S. EPA Inc.)

vol\% -

United States Environmental Protection Agency

percentage by volume 


\subsection{Introduction}

Conventional production of hydrogen via steam methane reforming (SMR) produces carbon dioxide emissions, a greenhouse gas. Dr. Nazim Muradov of Florida Solar Energy Center (FSEC) is working to develop a method for producing hydrogen that addresses this concern via thermocatalytic decomposition (TCD) of natural gas. In addition to producing hydrogen, the decomposition reaction also produces a solid carbon byproduct, which can be sold. The process is based on a single-step decomposition of hydrocarbons over a carbon catalyst as shown in the following reaction:

$$
\mathrm{CH}_{4 \text { (gas) }} \Leftrightarrow \mathrm{C}_{\text {(solid) }}+2 \mathrm{H}_{2 \text { (gas) }}
$$

The hydrogen rich gas stream is then separated from the carbon and purified using pressure swing adsorption (PSA). Where SMR theoretically produces 4 moles of hydrogen for every mole of methane, the stoichiometry of the thermocatalytic decomposition of methane allows only 2 moles of hydrogen per mole of methane. This technoeconomic analysis examines the technical and economic feasibility of producing hydrogen from thermocatalytic decomposition of natural gas and is based on Dr. Muradov's research and data.

\subsection{Natural Gas Composition}

Methane is the main component in natural gas and typically makes up over 80 vol\% of the constituents. The remaining components are ethane, propane, butane, hydrogen sulfide, nitrogen, and carbon dioxide. The amount of these compounds can vary greatly depending on the location of the wellhead. This economic analysis uses the typical natural gas pipeline composition listed in the Chemical Economics Handbook (Lacson 1999) and is shown in Table 1. Additionally, the study assumed that the natural gas delivered to the hydrogen production facility will be at the required reactor pressure.

\section{Table 1: Natural Gas Compositions}

\begin{tabular}{|l|c|c|c|}
\hline \multirow{2}{*}{ Component } & $\begin{array}{c}\text { Typical pipeline } \\
\text { composition }\end{array}$ & \multicolumn{2}{c|}{$\begin{array}{c}\text { Typical range of wellhead } \\
\text { components }(\mathrm{mol} \%)^{\mathrm{b}}\end{array}$} \\
\cline { 2 - 4 } & Mol \% (dry) & Low value & High value \\
\hline Methane $\left(\mathrm{CH}_{4}\right)$ & 94.4 & 75 & 99 \\
\hline Ethane $\left(\mathrm{C}_{2} \mathrm{H}_{6}\right)$ & 3.1 & 1 & 15 \\
\hline Propane $+\left(\mathrm{C}_{3}{ }^{+}\right)$ & 0.8 & 1 & 14 \\
\hline Nitrogen $\left(\mathrm{N}_{2}\right)$ & 1.1 & 0 & 15 \\
\hline Carbon dioxide $\left(\mathrm{CO}_{2}\right)$ & 0.5 & 0 & 10 \\
\hline Hydrogen sulfide $\left(\mathrm{H}_{2} \mathrm{~S}\right)$ & 0.0004 & 0 & 30 \\
\hline $\begin{array}{l}\text { Heat of combustion, } \\
\text { HHV }\end{array}$ & $\begin{array}{c}54,440 \mathrm{~J} / \mathrm{g} \\
(23,429 \mathrm{Btu} / \mathrm{lb})\end{array}$ & & - \\
\hline
\end{tabular}

${ }^{a}$ Source: Chemical Economics Handbook (Lacson 1999)

${ }^{\mathrm{b}}$ Source: Ullmann's Encyclopedia of Industrial Chemistry (1986)

\subsection{Process Descriptions for Hydrogen from Thermocatalytic Decomposition}

Because the thermocatalytic decomposition of methane is an endothermic process $(\Delta \mathrm{H}=-75.6$ $\mathrm{kJ} / \mathrm{mol}$ methane), the issue of supplying heat to the reactor resulted in the development of two different process designs. The first uses partial oxidation of some of the natural gas and carbon to 
provide the reaction heat within the reactor. The second uses a three vessel design that is similar to the flexicoking process found in oil refineries. In this design, the TCD reactor heat is provided by complete combustion of natural gas in a separate vessel. The hot offgas from the combustor is mixed with the recycled carbon in a fluidized bed and the recycled carbon supplies heat to the reactor. Both processes were modeled in ASPEN Plus ${ }^{\circledR}$ to determine the energy balance and heat integration of the system. The following sections further describe these two processes.

\subsection{Partial Oxidation System}

The partial oxidation system, shown in Figure 1, uses a fluidized bed reactor in which both partial oxidation and thermocatalytic decomposition reactions take place. The partial oxidation of natural gas and carbon inside the TCD reactor creates enough direct heat for the decomposition reaction, producing an offgas stream with $40 \%$ hydrogen (by volume) and a solid carbon byproduct. The system operates at $2.5 \mathrm{MPa}(367 \mathrm{psi})$ and oxygen is fed at a rate that maintains the reactor temperature at $850^{\circ} \mathrm{C}\left(1,562^{\circ} \mathrm{F}\right)$. It is assumed that the natural gas is obtained at the system operating pressure. However, a natural gas compressor is added in the sensitivity analysis to determine its effect on the hydrogen selling price (see results in Section 9.5.4). The reactor product stream is quenched with water to $370^{\circ} \mathrm{C}\left(700^{\circ} \mathrm{F}\right)$ to stop any further decomposition reactions. The equilibrium curves in Figure 2 show that methane decomposition at this quench temperature is very small.

After quenching the hot syngas, shift conversion $\left(\mathrm{CO}+\mathrm{H}_{2} \mathrm{O} \Leftrightarrow \mathrm{CO}_{2}+\mathrm{H}_{2}\right)$ was tested in the system design with the hope of increasing hydrogen production. However, adding this process step only resulted in a small increase in hydrogen production, while reducing the carbon byproduct by $50 \%$. With shift conversion, the PSA offgas stream contains mostly $\mathrm{CO}_{2}$ rather than $\mathrm{CO}$, thereby reducing the heat content of this stream. To compensate, more of the carbon is burned, resulting in a lower byproduct carbon credit and a higher hydrogen selling price.

Because the solid carbon exits the reactor in the gas stream, a series of cyclones is used to separate the carbon byproduct from the offgas. Cyclones are used because they have a high efficiency (greater than 98\%) for removing particles larger than 5 microns (Cooper and Alley 1994). Cyclones are made from a wide variety of materials and can also be refractory lined if a high temperature gas is fed to the cyclone $\left(982^{\circ} \mathrm{C}\right.$ or $\left.1,800^{\circ} \mathrm{F}\right)$ (ICARUS 1997). To protect downstream equipment, a separate filter is used to remove any carbon particles that may escape separation in the cyclone.

The filtered offgas stream is cooled to $38^{\circ} \mathrm{C}\left(100^{\circ} \mathrm{F}\right)$ to knock out the water prior to purification. At large scales, hydrogen separation by PSA is more economical than membrane separation. Additionally, PSA produces higher purity hydrogen (greater than 99\%), whereas membranes generally produce hydrogen at 90-98 vol\% (SRI 1994). For these reasons, PSA is used in the base case and membranes are examined in the sensitivity study (see Section 9.5.4). The partial oxidation design results in large concentrations of $\mathrm{CO}$ and $\mathrm{CO}_{2}$ in the PSA feed, so part of the product hydrogen is recycled to increase the concentration of hydrogen in the PSA feed to $70 \%$, by volume. Purification of streams more dilute than this decreases the product purity and recovery of hydrogen. For a $70 \mathrm{~mol} \%$ hydrogen PSA feed, a hydrogen recovery rate of $85 \%$ is typical with a product purity of $99.9 \mathrm{vol} \%$.

It is necessary to use oxygen for partial oxidation, rather than air, because the large concentration of nitrogen in the air will dilute the hydrogen concentration in the PSA feed gas. Nitrogen, like hydrogen, is weakly adsorbed onto the adsorbent bed in the PSA unit, reducing the hydrogen recovery rate for the same purity. Additionally, because the PSA offgas is recycled to the reactor, nitrogen would build up in the system, requiring a large purge stream. Recycling the PSA offgas stream allows more of the hydrogen to be recovered and greater conversion of methane to carbon 
Figure 1: Process Flowsheet for Thermocatalytic Decomposition of Natural Gas via Partial Oxidation

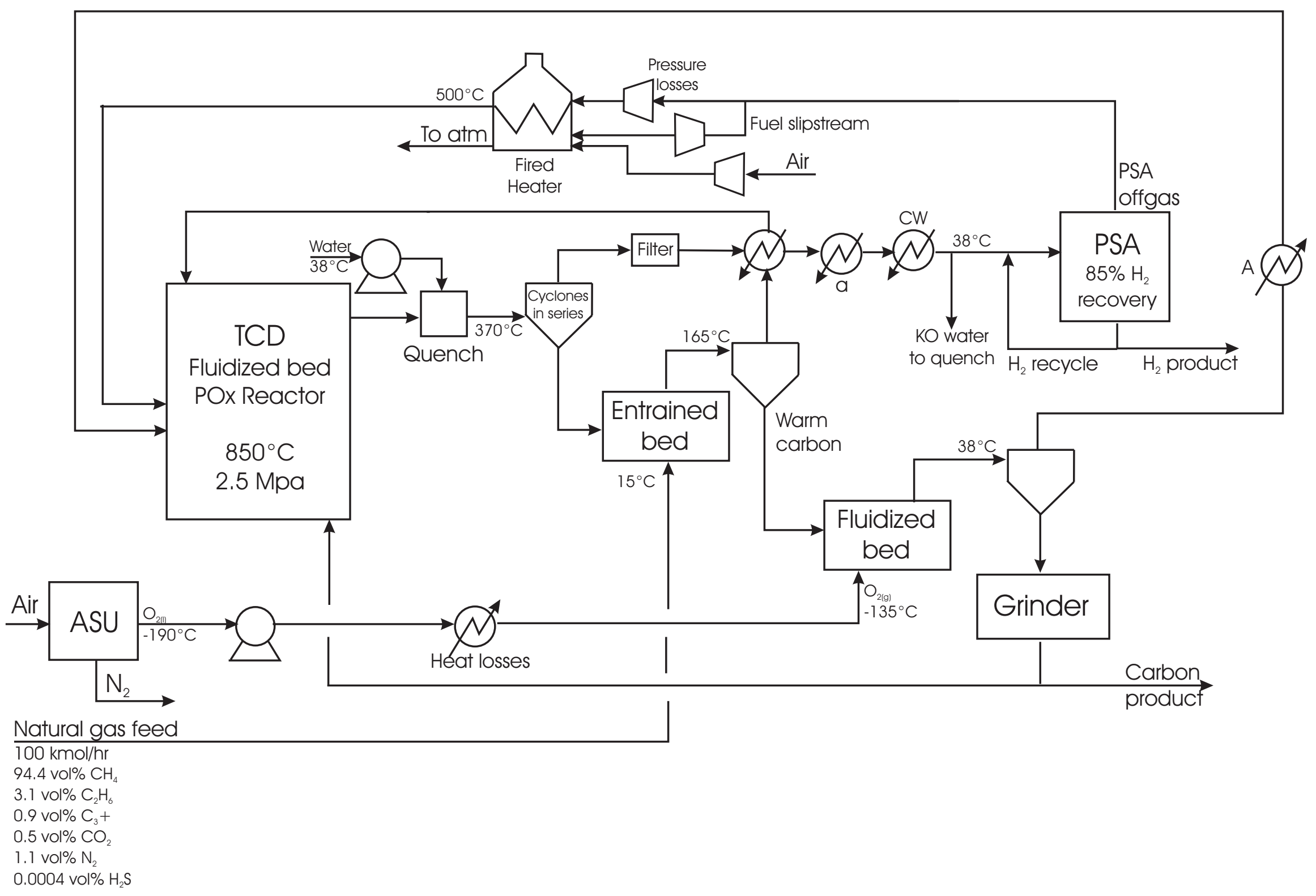


Figure 2: Thermal Decomposition of Methane Equilibrium Curve

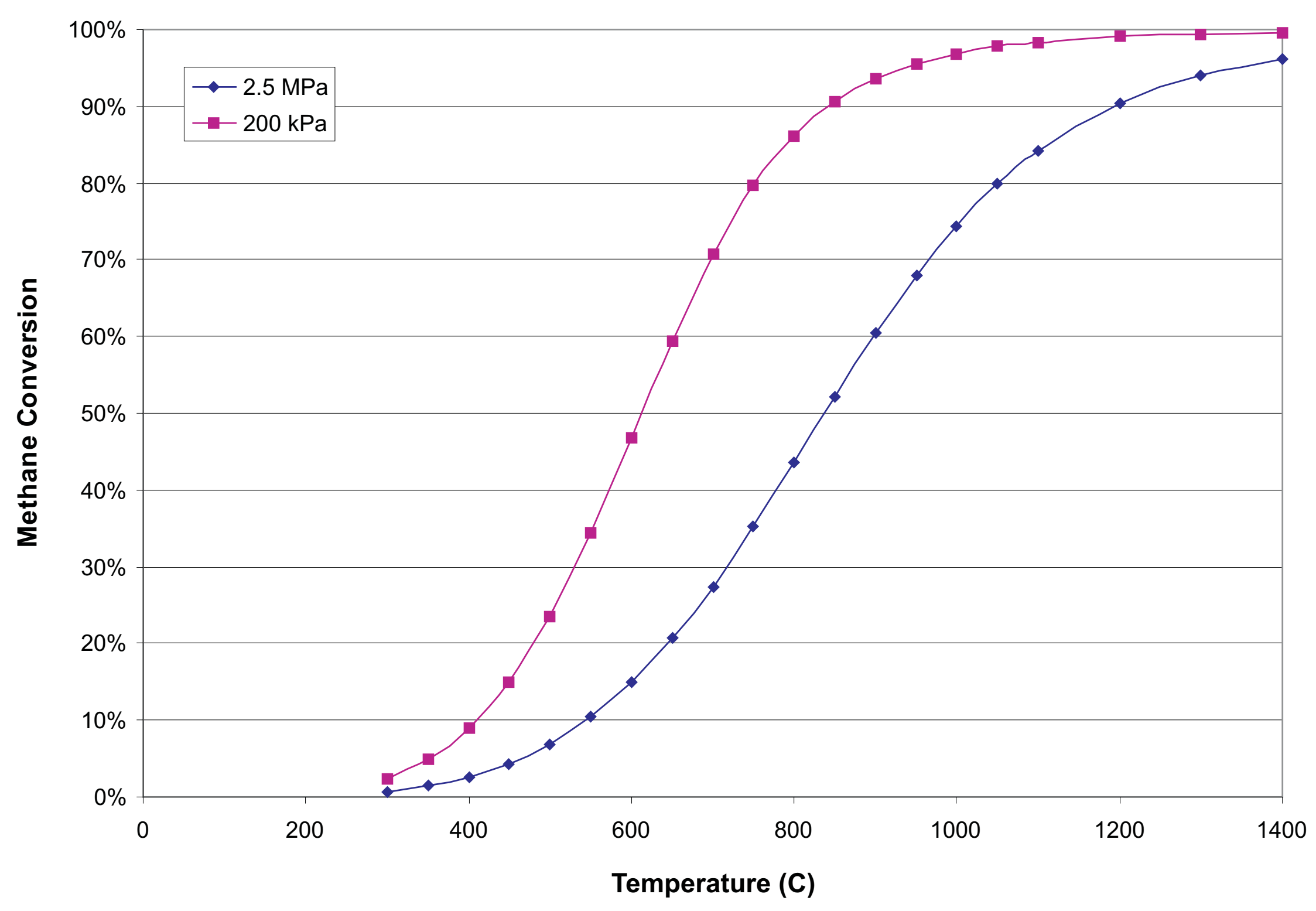


and hydrogen. A small purge stream is required to prevent accumulation of nitrogen from the natural gas feedstock (see the natural gas composition in Table 1) and carbon dioxide within the system. The purge stream is fed to the fired heater as fuel to preheat the PSA offgas before being fed to the reactor.

Because of the flammable nature of hot carbon in air, further cooling of the carbon (after quench) is attained by mixing the warm carbon with the natural gas feed in an entrained bed, then a cyclone is used to separate the carbon from the natural gas. The cooled carbon from the cyclone, now at $165^{\circ} \mathrm{C}\left(330^{\circ} \mathrm{F}\right)$, is mixed with a gaseous oxygen feed from the air separation unit for additional cooling and separated again. At this point, the carbon is below the ignition temperature for an oxidizing atmosphere $\left(350^{\circ} \mathrm{C}\right.$ or $660^{\circ} \mathrm{F}$ for graphite) (Perry and Green 1997), so the carbon will not combust in the fluidized bed.

In addition to cooling down the carbon, these vessels also preheat the natural gas and oxygen feeds to the reactor. The cooled carbon is sent through a grinder to increase the activity and also to meet anticipated carbon product specifications. "Practically every solid material undergoes size reduction at some point in its processing cycle. Some of the reasons for size reduction are . . to meet a size requirement for the quality of the end product (Perry and Green 1997)." After grinding, the carbon stream is split and a small portion of the recycled carbon is burned in the POx reactor for heat.

\subsection{Three Vessel System}

The second process is one that resembles the flexicoking process in which coke is produced by the decomposition of refinery residuum. In the flexicoking design, the reactor is heated by hot coke which is cycled between the reactor and a heater vessel. Heat is supplied to the heater vessel via gasification of the coke product. The three vessel design used in this analysis has heat integration similar to this. As in the flexicoking system, a fluidized bed heater acts as a heat exchange vessel between the combustor and the fluidized bed reactor (see Figure 3). However, instead of combusting the product carbon for heat, natural gas is burned with 5\% excess air for complete combustion in a

separate vessel. This was found to be more economical than burning carbon. Note that if combustion of the natural gas and heating of the carbon were to take place in one vessel, all the carbon would be burned and partial combustion of the natural gas would result in a higher natural gas requirement to provide enough heat to the reactor.

For complete combustion, carbon reacts with oxygen to produce $32.8 \mathrm{MJ}$ of heat per kilogram of carbon (14,100 Btu/lb of C) (Perry and Green 1984). If incomplete combustion take place, CO is formed, producing only $10.1 \mathrm{MJ} / \mathrm{kg}$ of C (4,350 Btu/lb of C) (Perry and Green 1984). This is why it is beneficial from a heat integration standpoint to carry out complete combustion of the natural gas, prior to mixing the hot gas with the carbon. Also, from an environmental standpoint, the offgas stream from incomplete combustion will have a high $\mathrm{CO}$ content and this must be completely combusted before being released to the atmosphere.

The hot offgas from the combustor provides heat to the carbon which is recycled to the TCD reactor. Around $15 \%$ of the carbon in the heater feed is burned in the heater as a result of the excess air in the combustor offgas stream. This results in a lower amount of carbon product per amount of hydrogen produced than for the partial oxidation system, and thus, a lower byproduct credit. However, again excess air is necessary for complete combustion of the natural gas.

A quench is also necessary in this process to stop any further decomposition reactions. The PSA in this system has the same operating conditions as that of the partial oxidation system described above, however, no hydrogen recycle is necessary in this case since the hydrogen concentration in the PSA 
Figure 3: Process Flowsheet for Thermocatalytic Decomposition of Natural Gas using Three Vessels

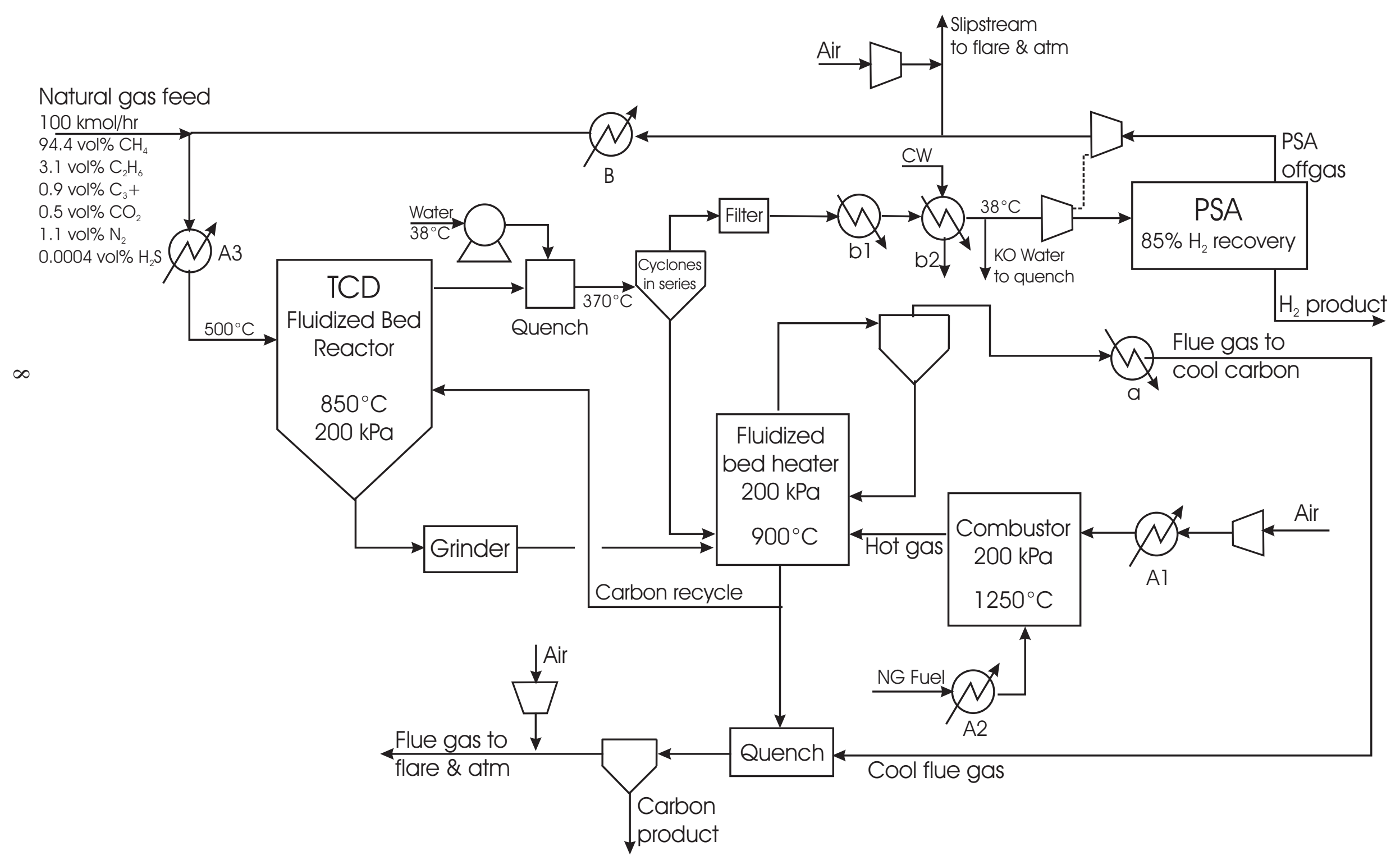


feed is above $70 \mathrm{vol} \%$. With the exception of the PSA block, the remainder of the system operates at $200 \mathrm{kPa}(29 \mathrm{psi})$. The PSA feed is compressed to $2.5 \mathrm{MPa}$ (367 psi) and part of the work is recovered by expanding the offgas in a turbine. A small purge stream is necessary to prevent buildup of nitrogen, carbon monoxide, and carbon dioxide within the recycle loop. Again, the nitrogen is from the natural gas feedstock.

In the three vessel system, the gas stream leaving the fluidized bed reactor is also cooled via water quench to stop decomposition reactions. Although most of the product carbon leaves through the bottom of the fluidized bed reactor, any carbon entrained in the gas exiting the reactor is separated using cyclones in series similar to the POx system. Again, the reactor synthesis gas passes through a filter prior to cooling and hydrogen purification. Like the POx design, the carbon leaving the TCD reactor is ground to increase the activity and also to meet anticipated carbon product specifications.

\subsection{Related Processes}

Several process were found that are similar to that studied in this analysis. The fluid coking and carbon black processes are used commercially to produce carbon. As mentioned earlier (Section 3.2), the three vessel design was based on the process for producing coke via flexicoking. Additional commercial methods for producing carbon are discussed below.

\subsection{Fluid Coking Process}

Fluid coking varies from flexicoking in that only two reactors are used in fluid coking, a reactor and a burner. Additionally, fluid coking operates at atmospheric pressure and at a temperature lower than the TCD reactor; $480^{\circ} \mathrm{C}-540^{\circ} \mathrm{C}$ versus $850^{\circ} \mathrm{C}$ (Massenzio and Meyers 1984). In the fluid coking process, a small portion (20\%-25\%) of the coke produced in the reactor is burned to satisfy the system heat requirements (Gary 1994). A product scrubber is mounted on top of the reactor to quickly quench the reactor effluent vapors and to provide the first stages of fractionation and heat recovery.

\subsection{Carbon Black Process}

Carbon black used to be made via the channel black process, but this process has been abandoned because of economic and environmental considerations. The thermal black process is used today for producing carbon black and uses natural gas as a feedstock. A thermal black plant consists of two furnaces, which are used in alternate heating and production periods lasting 5 minutes in duration (Ullmann 1986). The products leaving the furnace, carbon black and nearly pure hydrogen, are cooled by injecting water into an ascending channel. The carbon black is then separated from the syngas in a collection system using bag filters or cyclones.

\subsection{Hypro Process}

In the Hypro process from Universal Oil, hydrocarbons are catalytically decomposed to hydrogen and carbon in a two-vessel, reactor-regenerator system. Burning of the carbon produced in the reaction provides enough energy for the reactor. One difference between the Hypro process and the designs in this analysis is that the carbon is absorbed on an iron oxide catalyst and stripped off by burning with air to produce a mixture of $\mathrm{CO}$ and $\mathrm{CO}_{2}$ that can later be used for heat. Hypro was investigated in the early ' $60 \mathrm{~s}$ as a low-cost route for salvaging hydrogen already contained in offgases from hydrocracking units and other processes (Pohlenz and Stine 1962). 


\subsection{HYDROCARB Process}

Developed by Brookhaven National Laboratory, the HYDROCARB process was conceived for producing carbon black from carbonaceous raw materials, the most abundant of which is coal (Steinberg 1995). This two-step process consists of hydropyrolysis of the carbonaceous raw material with excess hydrogen, producing a methane-rich process gas which is then thermally decomposed in a separate reactor, producing hydrogen and carbon black. In the thermocatalytic decomposition reaction, kinetics are favored at higher pressures, but equilibrium is favored at lower pressures (Steinberg 2001). The equilibrium curves in Figure 2 show greater methane conversion at higher temperatures and lower pressures. Dr. Muradov's setup is run at lower pressures than the HYDROCARB process ( 2 and 25 atm for the three vessel and POx system, respectively, versus 50$60 \mathrm{~atm})$, favoring equilibrium.

\subsection{Carbon Market and Uses}

In general, carbon can be classified as activated carbon, carbon black, or graphitic carbon. The following sections give information on these types of carbon.

\subsection{Activated Carbon}

Activated carbon is a predominantly amorphous form of elemental carbon prepared by thermal conversion of any one of a variety of carbonaceous raw materials, including wood, coal, or coconut shells. Worldwide production of activated carbon was 0.328 million metric tons in 1998 with 0.164 million metric tons produced in the U.S. (SRI 1999). This type of carbon is used as a substrate primarily to selectively adsorb gases, vapors, or colloidal solids from liquids or gases. The major worldwide markets for activated carbon, are listed below in descending order, by size (SRI 1999).

- $\quad$ water treatment

- $\quad$ chemical, pharmaceutical, and mineral processing

- $\quad$ air and gas purification

- $\quad$ food processing

- $\quad$ sweetener decolorizing

- $\quad$ solvent vapor recovery

\subsection{Carbon Black}

There is a large market potential for carbon black, both within the traditional rubber industry as well as within new markets. Carbon black has the largest worldwide production of the three types (activated carbon, carbon black, and graphite carbon) at 7.9 million metric tons per year (SRI 1999). The majority of carbon black (70\%) is used in the production of tires. Most of the remaining carbon $(22 \%)$ is used in the industrial rubber products industry. Other miscellaneous uses include printing inks, paints, and plastics. The carbon black industry produces a whole range of grades (about 40 grades), which are classified according to surface area and structure of the carbon black particles. The higher the surface area, the finer the carbon black grade and the higher the price obtained per unit of carbon black.

\subsection{Graphitic Carbon}

Graphite is a crystalline form of elemental carbon. Of the four basic types of graphite, three of the four occur naturally as minerals and the other is produced synthetically. The natural grades include crystalline flake, crystalline vein, and microcrystalline (also known as amorphous). End uses for natural graphite include refractories, lubricants, brake linings, pencils, batteries, and paints. 
Synthetic graphite has a higher carbon content (above 99\%) but lower crystallinity than natural graphite. Annual worldwide production of natural graphite is 0.718 million metric tons and production of synthetic graphite is 0.280 million metric tons (SRI 1997).

The largest use of synthetic graphite is as electrodes in electric-arc furnaces for the production of steel. In this high temperature environment, graphite is particularly suitable as it retains its good stability and electrical conductivity. As a result, potential growth in the area of graphite electrodes is closely linked to potential growth in the steel industry. Synthetic graphite can be made in one of two ways: 1) as a byproduct of the electrode manufacturing process or 2) by mixing carbonaceous filler and binder materials, shaping by extrusion or molding, and baking at $1,000^{\circ} \mathrm{C}\left(1,832^{\circ} \mathrm{F}\right)$ in an inert or reducing atmosphere (SRI 1997). High-purity synthetic graphite is being developed as a carbon additive for the iron and steel industry and is also being used in alkaline and lithium dry batteries, a market segment already showing good growth with increased use of compact computers, cellular telephones, camcorders, and electric automobiles.

Synthetic graphite is also produced from calcined petroleum coke. The degree to which the coke is broken down depends on the grade of graphite to be made. If the product is to be a fine-grained variety for use in aerospace, metallurgical, or nuclear applications, milling and pulverizing operations are used to produce sizes as small as a few micrometers in diameter. If, on the other hand, the product is to be coarse in character for products like graphite electrodes used in manufacturing steel, a high yield of particles up to $25 \mathrm{~mm}$ in diameter is necessary. Graphite dispersed in solvents is used for drawing, extruding, and forming aluminum and magnesium, as a high temperature lubricant for conveyors, and for a variety of industrial applications (Kirk-Othmer 1992). Carbon graphite produced as a lubricant is sold at a high price, and depends on the proper use of additives and impregnates in the materials.

\subsection{Market for Carbon Product from Thermocatalytic Decomposition}

One possible use for Dr. Muradov's carbon is in graphite electrodes where pure carbon is used in the production of aluminum. Carbon is used in the manufacture of aluminum in the electrowinning process (separation of aluminum by electrolysis). Electrolytic reduction of alumina occurs in shallow rectangular cells, or "pots", which are steel shells lined with carbon (U.S. EPA 1998). Carbon electrodes extending into the pot serve as the anodes, and the carbon lining serves as the cathode. The carbon anodes are continuously depleted in the following reaction:

$$
2 \mathrm{Al}_{2} \mathrm{O}_{3}+3 \mathrm{C} \Rightarrow 4 \mathrm{Al}+3 \mathrm{CO}_{2}
$$

Petroleum coke is the major source of carbon for these anodes. Because $0.4-0.5 \mathrm{~kg}$ of anode is consumed per $\mathrm{kg}$ of aluminum produced, this represents a large carbon requirement. Ash from the carbon will contaminate either the aluminum produced or the electrolyte, therefore, high-purity carbon is desirable in the cathode lining (Frank et al 2001). The ash content of the petroleum coke is dependent upon the oil feedstock. With the exception of carbon used to manufacture aluminum, the largest use of graphitic carbon is as electrodes in electric-arc furnaces (Kirk-Othmer 1992).

The carbon produced from Dr. Muradov's thermal decomposition process is around 100 microns in size and free of impurities (sulfur and ash). This clean carbon will obtain a higher selling price than carbon produced from petroleum products, which contain sulfur and ash impurities. Lab tests performed by AMIA Laboratories-Rigaku show that the carbon produced from Dr. Muradov's 
experimental apparatus has ordering in the "columnar" or stacking direction, which is typical of graphite (Muradov 2000). UOP has also performed independent scanning electron microscope and X-ray spectroscopic tests of the carbon product. Like AMIA Labs, UOP has also concluded that the carbon has a graphitic structure (Muradov 2000). The base case of this analysis assumes a carbon selling price of $\$ 0.30 / \mathrm{kg}$, based on UOP's estimates for similar grade carbon (Muradov 2001). This is comparable to other graphitic carbon selling prices and lower than the selling prices of N550 grade carbon black and activated carbon (see Table 2). The carbon selling price was varied as a Monte Carlo assumption variable and independently of the other assumptions in the sensitivity analysis (see results in Section 9.5.2).

Table 2: Carbon Selling Prices

\begin{tabular}{|l|l|c|l|}
\hline \multicolumn{1}{|c|}{ Carbon Type } & \multicolumn{1}{c|}{ Grade } & Price $(\$ / \mathrm{kg})$ & \multicolumn{1}{c|}{ Source } \\
\hline Graphitic Carbon & Amorphous powder & $\$ 0.22-0.30$ & SRI 1997 \\
\hline Graphitic Carbon & Crystalline graphite & $\$ 0.37-0.41$ & SRI 1997 \\
\hline Carbon Black & N550 & $\$ 0.66$ & $\begin{array}{l}\text { Chemical Marketing } \\
\text { Reporter 2001 }\end{array}$ \\
\hline Carbon Black & N550 & $\$ 0.78$ & Chemical Week 2001 \\
\hline Carbon Black & Various & $\$ 0.76-1.08$ & SRI 1999 \\
\hline Activated Carbon & Powdered & $\$ 0.70-1.20$ & SRI 1999 \\
\hline Activated Carbon & Granular & $\$ 1.30-1.90$ & SRI 1999 \\
\hline
\end{tabular}

\subsection{Economic Analysis Assumptions}

Three plant sizes were investigated in this analysis. The small plant size produces enough hydrogen for 50 refueling stations, assuming a filling station services 100 cars per day and each fuel cell vehicle uses $3 \mathrm{~kg} \mathrm{H}_{2} /$ week. This gives a small plant size of $0.16 \mathrm{Nm}^{3} /$ day ( $\left.6 \mathrm{MMscfd}\right)$. The medium and large size plants produce 0.53 , and $1.58 \mathrm{Nm}^{3} /$ day (20 and $\left.60 \mathrm{MMscfd}\right)$ of hydrogen, respectively. Table 3 shows the economic assumptions used in this analysis.

Table 3: General Economic Assumptions

\begin{tabular}{|l|c|}
\hline \multicolumn{1}{|c|}{ Assumption } & Value \\
\hline $\begin{array}{l}\text { After-tax internal rate of } \\
\text { return }\end{array}$ & $15 \%$ \\
\hline Depreciation & MACRS $^{\mathrm{a}}$ \\
\hline Recovery period & 10 years \\
\hline Plant life & 20 years \\
\hline Capacity factor & $90 \%$ \\
\hline Working capital & $18 \%$ of fixed capital \\
\hline Interest rate & $10 \%$ \\
\hline
\end{tabular}




\begin{tabular}{|l|c|}
\hline \multicolumn{1}{|c|}{ Assumption } & Value \\
\hline Salvage value & $10 \%$ \\
\hline $\begin{array}{l}\text { Capital-investment based } \\
\text { on ratio factors }\end{array}$ & $\begin{array}{c}315 \% \text { of delivered } \\
\text { equipment cost }\end{array}$ \\
\hline Cost of labor & $\$ 33.67 / \mathrm{hr}^{\mathrm{c}}($ loaded $)$ \\
\hline Cost of electricity & $\$ 0.045 / \mathrm{kWh}^{\mathrm{d}}$ \\
\hline
\end{tabular}

${ }^{a}$ MACRS - Modified Accelerated Cost Recovery System (Declining balance switching to straight line)

${ }^{\mathrm{b}}$ Source: Peters and Timmerhaus (1991) Plant design and Economics for Chemical Engineers

${ }^{c}$ Source: 1995 PEP yearbook (includes costs of fringe benefits and 10\% shift overlap in 2000\$.

d Source: Energy Information Administration's U.S. Electric Power Industry Summary Statistics (2000).

The cash flow spreadsheets were created on the basis of a Discounted Cash Flow Rate of Return (DCFROR) analysis. DCFROR is defined as the rate of return that makes the after-tax net present value equal to zero. The hydrogen selling prices for the base cases and Monte Carlo sensitivity analyses were calculated for a $15 \%$ after-tax internal rate of return (IRR) because this is a typical hurdle rate before a project is considered economically viable. The sensitivity of hydrogen selling price to IRR is shown in Section 9.5.3. The economics in this report use 2000 U.S. dollars as the basis.

\subsection{Capital Cost Estimates}

Almost all of the capital costs were estimated using Questimate ${ }^{\mathcal{O}}$ from ICARUS. The PSA and oxygen plants' capital and operating cost were calculated from a previous analysis (Spath et al 2000a). Additionally, because the operating conditions of the partial oxidation reactor are similar to the Institute of Gas Technology's high pressure direct-fired gasifier costed in a past analysis (Spath et al 2000a), the POx reactor capital cost was estimated using those costs.

Economies of scale were applied to estimate capital costs using the logarithmic relationship known as the six-tenths-factor rule (Peters and Timmerhaus 1991). According to this rule, if the cost of a given unit at one capacity is known, the cost of a similar unit with $\mathrm{X}$ times the capacity of the first is approximately $(X)^{a}$ times the cost of the initial unit, where $a=0.6$. Peters and Timmerhaus (1991) also gives values for "a" based on the specific equipment type. When applicable, these factors were incorporated into this analysis.

$$
\text { Cost of } \mathrm{A}=\text { Cost of } \mathrm{B} *\left(\frac{\text { Capacity of } \mathrm{A}}{\text { Capacity of } \mathrm{B}}\right)^{\mathrm{a}}
$$

\subsection{Natural Gas Cost}

Due to the volatility and unpredictability of natural gas costs, the hydrogen selling price is presented as a function of natural gas cost, and therefore, is not a variable in the Monte Carlo Analysis. The base case cost is based on EIA's year 2000 selling price to industrial consumers of $\$ 3.72 / \mathrm{GJ}$ (\$3.92/MMBtu) (EIA 2001). The 1998 cost of natural gas was $\$ 2.90 / \mathrm{GJ}$ (\$3.05/MMBtu) and the most recent cost is $\$ 5.32 / \mathrm{GJ}$ (\$5.05/MMBtu) for October 2000 (EIA 2001). Natural gas prices are 
predicted to rise, so based on these data and predictions, the natural gas cost is varied between $\$ 2.9$ and \$6.6/GJ (\$3 and \$7/MMBtu).

\subsection{Membrane for Hydrogen Purification}

Membranes are the lowest capital cost alternative for small flow rates (less than $0.13 \mathrm{Nm}^{3} /$ day of product), excluding the cost for compression (SRI 1994). The membrane examined in this analysis uses a feed gas at $2.5 \mathrm{MPa}(367 \mathrm{psi})$ and $90^{\circ} \mathrm{C}\left(194^{\circ} \mathrm{F}\right)$ based on operating requirements obtained by Dr. Muradov. This membrane recovers $75 \%$ of the hydrogen at a purity of $99 \%$. SRI (1994) states that membranes generally produce hydrogen at $90-98 \mathrm{vol} \%$ and are not used if very high purity hydrogen is required. The hydrogen inlet concentration for membranes can range from $20 \%-85 \%$ (SRI 1994), although a lower hydrogen content in the feed decreases the hydrogen recovery rate. The economics of hydrogen purification using a membrane are examined and compared with purification from PSA. This is another variable that could not be changed using Monte Carlo analysis because the membrane has different operating requirements from PSA and requires a separate ASPEN Plus ${ }^{\circledR}$ simulation to account for the reduced hydrogen purity, higher membrane feed temperature, and no hydrogen recycle.

\subsection{Sensitivity Analysis Using Crystal Ball ${ }^{\circledR}$}

Crystal Ball ${ }^{\circledR}$ is a software package from Decisioneering that incorporates uncertainty of the assumption variables into the forecast results. Crystal Ball ${ }^{\circledR}$ generates random numbers for a probability distribution over the entire range of possible values, based on the assumption variables. This software is able to predict the sensitivity of the hydrogen selling price to changes in various analysis parameters, and determines which of the parameters contribute the greatest uncertainty to the results. All of the parameters are varied at once, giving a mean hydrogen selling price that incorporates the combined uncertainty of the assumption variables. For this reason, a large number of trials are required to obtain accurate results for the true shape of the distribution. With Latin Hypercube sampling used in this analysis, an assumption's probability distribution is divided into intervals of equal probability. Crystal Ball ${ }^{\circledR}$ then generates an assumption value for each interval according to the interval's probability distribution. Compared with conventional Monte Carlo sampling, Latin Hypercube sampling is more precise because the entire range of the distribution is sampled in a more even and consistent manner.

The following is a list of the variables that were changed in the analysis. The variables are listed randomly and should not be considered to be listed relative to importance.

\section{Variable: Hydrogen production factor}

Often a process will perform better or worse than the actual design. In order to compensate for this, the hydrogen production factor was assigned a uniform distribution from 0.9 to 1.1 . This means that the system has an equal probability of producing between $90 \%$ to $110 \%$ of the design hydrogen production rate. This is different from operating capacity factor, and is meant to capture the possibility of a lower or higher hydrogen yield. Changes in the syngas composition from the TCD reactor would result in changes in the hydrogen recovery rate from the PSA unit. The hydrogen production factor variable accounts for changes in the PSA feed composition. 
Variable: Carbon yield

The yield of carbon was determined from the ASPEN Plus ${ }^{\circledR}$ simulation results. ASPEN Plus ${ }^{\circledR}$ gave carbon yields of $0.544 \mathrm{~kg}$ carbon $/ \mathrm{kg}$ natural gas for the partial oxidation system and $0.497 \mathrm{~kg}$ carbon/kg natural gas for the three vessel system. These values are close to Dr. Muradov's experimental carbon yield which is $0.54 \mathrm{~kg}$ carbon $/ \mathrm{kg}$ natural gas. A triangular distribution was used with a minimum yield of $0.272 \mathrm{~kg}$ carbon $/ \mathrm{kg}$ natural gas for the partial oxidation system and 0.249 $\mathrm{kg}$ carbon/ $\mathrm{kg}$ natural gas for the three vessel system (based on 50\% reduction of ASPEN's yields). The maximum yield was set at $0.739 \mathrm{~kg}$ carbon $/ \mathrm{kg}$ natural gas, based on the amount of carbon entering in the natural gas.

Variable: Carbon selling price

As discussed in Section 6.0, the base case carbon selling price of $\$ 0.30 / \mathrm{kg}$ is based on UOP's carbon analysis. Table 2 shows carbon selling prices in the literature with $\$ 0.30 / \mathrm{kg}$ falling between the two prices given for graphitic carbon. Both processes use a normal distribution with a mean of $\$ 0.30 / \mathrm{kg}$, $\$ 0 / \mathrm{kg}$ as the minimum, and a standard deviation of $10 \%$.

Variable: Operating capacity factor

The base case uses an average operating capacity of $90 \%$. The amount of time that the hydrogen plant operates can vary depending on factors such as downtime due to maintenance. Therefore, the mean was set at $100 \%$ with a standard deviation of $10 \%$. Although a normal distribution was used, the minimum and maximum values were restricted to $0 \%$ and $110 \%$, respectively. An operating capacity greater than $100 \%$ is possible if hydrogen demand were high and the plant operated past its design limits.

Variable: Working capital

Working capital is assumed to be a percentage of the total fixed capital investment. This variable was modeled using a triangular distribution with a range of $10 \%-20 \%$ and the likeliest value being $18 \%$, based on percentages given in the following literature sources: Garrett (1989), Peters and Timmerhaus (1991), and Turton, et al (1998).

Variable: Percent of capital recovered as salvage

At the end of the hydrogen plant's life, the base case assumes that $10 \%$ of the depreciable capital can be recovered as salvage. A normal distribution with a standard deviation of 1 percentage point (or $10 \%$ of $10 \%$ ) was used for this variable.

Variable: Capital cost multipliers

Multipliers were used for scaling the capital costs of the reactor, oxygen plant, PSA unit, and compressors. These were the most expensive pieces of equipment and combined, result in about $95 \%$ of the total capital cost for both systems studied. Heat exchangers, pumps, grinders, filters, cyclones, and tanks made up the remaining 5\%, so a different equipment cost multiplier was applied to each of these pieces of equipment. A cost multiplier of 1 means that the capital cost as determined by Questimate $^{\mathcal{O}}$ or literature sources was the actual cost of the equipment. A multiplier greater than 1 indicates that the capital cost would be greater than the estimated value while a number less than 1 means that the cost would be less. In other words, the actual equipment cost ended up being the determined cost times the specified cost factor. For example, a cost multiplier of 0.9 , means that the cost of that particular piece of equipment was actually $90 \%$ of the predicted cost. Each piece of equipment was assumed to have a uniform distribution with a minimum and maximum value as listed in Table 4. 
Table 4: Equipment Cost Multipliers

\begin{tabular}{|l|c|c|}
\hline \multicolumn{1}{|c|}{ Equipment } & Minimum & Maximum \\
\hline Reactor & 0.85 & 1.3 \\
\hline Oxygen plant & 0.8 & 1.2 \\
\hline PSA unit & 0.7 & 1.3 \\
\hline Compressors and pumps & 0.9 & 1.1 \\
\hline Other equipment & 0.7 & 1.3 \\
\hline
\end{tabular}

Variable: Cost factors for capital investment

In these analyses, cost factors were used to estimate the equipment installation costs. These factors are for estimating the capital investment based on the total delivered equipment cost. A triangular distribution was used for each parameter and the following table contains the minimum, most likely, and maximum values used in the sensitivity analysis. The values shown in Table 5 are based on ranges given in Garrett (1989) and Peters and Timmerhaus (1991).

Table 5: Direct and Indirect Cost Multipliers

\begin{tabular}{|l|c|c|c|}
\hline \multicolumn{1}{|c|}{ Parameter } & Minimum & Most Likely & Maximum \\
\hline Electrical & $10 \%$ & $11 \%$ & $15 \%$ \\
\hline Instrumentation & $10 \%$ & $18 \%$ & $35 \%$ \\
\hline Piping & $50 \%$ & $66 \%$ & $70 \%$ \\
\hline Buildings & $15 \%$ & $18 \%$ & $30 \%$ \\
\hline Land & $4 \%$ & $6 \%$ & $10 \%$ \\
\hline $\begin{array}{l}\text { Yard } \\
\text { improvements }\end{array}$ & $5 \%$ & $10 \%$ & $15 \%$ \\
\hline Service facilities & $40 \%$ & $70 \%$ & $80 \%$ \\
\hline $\begin{array}{l}\text { Engineering \& } \\
\text { construction }\end{array}$ & $35 \%$ & $74 \%$ & $80 \%$ \\
\hline Contingencies & $25 \%$ & $42 \%$ & $80 \%$ \\
\hline
\end{tabular}

Variable: Interest rate

The mean interest rate for debt was set at $10 \%$ based on the high-risk nature of these new technologies. For the sensitivity runs, a normal distribution with a one percentage point standard deviation was assumed.

Variable: Wage rate

The wage rate is based on the $1995 \mathrm{PEP}$ yearbook estimate of $\$ 28.75 / \mathrm{hr}$ which includes both fringe benefits and shift overlap (SRI 1995). This rate was updated using Chemical Engineering magazine's hourly earnings index for chemical and allied products to ratio the 1995 estimate to an early 2000 rate. This current wage rate was calculated at $\$ 33.67 / \mathrm{hr}$, so a normal distribution was assumed for this variable with a mean of $\$ 33.67 / \mathrm{hr}$ and a $10 \%$ standard deviation. 
Variable: Cost of electricity

The cost of electricity was based on data from the Energy Information Administration (EIA 2001). The average retail price of electricity for industrial users in 2000 was $\$ 0.0448 / \mathrm{kWh}$. To account for variations in electricity prices in various regions throughout the U.S., a triangular distribution was set ranging from $\$ 0.04-\$ 0.08 / \mathrm{kWh}$ with the likeliest value being $\$ 0.0448 / \mathrm{kWh}$. Electricity prices have been very volatile over the past year and have been increasing with the rise in natural gas prices.

Variable: Steam selling price

A small amount of low pressure steam is produced in cooling the PSA feed stream. If this steam can be used for another process nearby, a steam credit can be taken in the economics. Based on data listed in Peters and Timmerhaus (1991) and Turton, et al (1998), the low pressure steam selling price was set up as a triangular distribution with the most likely value being $\$ 5.15 / \mathrm{Mg}$ of steam for the 0.7 MPa (100 psi) steam. The minimum value was set at zero, in the event that a nearby steam buyer is unavailable. The maximum selling price for the low pressure steam was set at $\$ 7.08 / \mathrm{Mg}$.

Variable: River water costs

The water costs were determined based on utility costs in Peters and Timmerhaus (1991) and Turton, et al (1998). Because there was a range of values for river water costs, a triangular distribution was set up with the minimum, likeliest, and maximum values being $\$ 0.02 / 1,000$ liters, $\$ 0.05 / 1,000$ liters, and $\$ 0.07 / 1,000$ liters, respectively.

\subsection{Analysis Results}

The following table shows the mass balance results at $100 \%$ capacity for both systems.

Table 6: Mass Balance Results for Varying Plant Sizes

\begin{tabular}{|l|c|c|c|}
\hline & $\begin{array}{c}\text { Small Plant } \\
(\mathrm{kg} / \mathrm{hr})\end{array}$ & $\begin{array}{c}\text { Medium Plant } \\
(\mathrm{kg} / \mathrm{hr})\end{array}$ & $\begin{array}{c}\text { Large Plant } \\
(\mathrm{kg} / \mathrm{hr})\end{array}$ \\
\hline \multicolumn{4}{|l|}{ Partial oxidation system } \\
\hline Hydrogen produced & 625 & 2,124 & 6,371 \\
\hline Carbon produced & 2,317 & 7,874 & 23,620 \\
\hline Natural gas feed & 4,263 & 14,490 & 43,460 \\
\hline Three vessel system & 625 & 2,124 & 6,371 \\
\hline Hydrogen produced & 1,355 & 4,604 & 13,810 \\
\hline Carbon produced & 2,727 & 9,267 & 27,800 \\
\hline Natural gas feed & 662 & 2,250 & 6,749 \\
\hline $\begin{array}{l}\text { Natural gas fuel for } \\
\text { combustion }\end{array}$ & 3,389 & 11,520 & 34,550 \\
\hline $\begin{array}{l}\text { Total natural gas } \\
\text { requirement }\end{array}$ & & & \\
\hline
\end{tabular}

From the information in Table 6 , it can be seen that for the same hydrogen production rate, the partial oxidation system has a higher natural gas requirement (26\%) but produces more byproduct 
carbon $(71 \%)$ than the three vessel system. Because partial oxidation does not produce as much heat as complete combustion, more natural gas is needed to provide heat to the reactor. In the three vessel system, complete combustion occurs in a separate vessel, so less natural gas is needed.

Assuming the carbon produced is marketed as synthetic carbon, the carbon from the large hydrogen production facility accounts for 3.1\% of the worldwide market share in the partial oxidation system and $1.8 \%$ of the market in the three vessel system. While this amount of carbon will not flood the market, implementing multiple plants even at the small scale would ultimately lower the carbon byproduct selling price. The sensitivity of the hydrogen selling price to the carbon selling price is further examined in the sensitivity analysis (see Section 9.5.2 for results).

\subsection{Hydrogen and Carbon Yields}

The yields produced from each ASPEN Plus ${ }^{\circledR}$ simulation, along with Dr. Muradov's experimental yields are shown in Table 7.

Table 7: Hydrogen and Carbon Yields

\begin{tabular}{|l|c|c|c|}
\hline & $\begin{array}{c}\text { Hydrogen Yield } \\
\left(\mathrm{kg} \mathrm{of} \mathrm{H}_{2} / \mathrm{kg} \text { natural gas fed }\right)\end{array}$ & $\begin{array}{c}\text { Carbon Yield } \\
(\mathrm{kg} \text { of C/kg natural gas fed })\end{array}$ & $\begin{array}{c}\text { Carbon Yield } \\
\left(\mathrm{kg} \mathrm{of} \mathrm{C} / \mathrm{kg} \mathrm{H} \mathrm{H}_{2}\right.\end{array}$ \\
\hline Partial Oxidation & 0.15 & 0.54 & 3.6 \\
\hline Three Vessel & 0.23 & 0.50 & 2.2 \\
\hline FSEC's Lab Data & 0.11 & 0.54 & 4.9 \\
\hline
\end{tabular}

The carbon yields are similar to Dr. Muradov's yield because a carbon split of $42 \%$ to product and $58 \%$ recycled, estimated by Dr. Muradov at FSEC, fulfilled the heat requirement of both simulations. The hydrogen yield is higher because recycling the offgas stream from the PSA unit allows for higher conversion of the natural gas. The POx recycle stream contains $12 \%$ methane and $26 \%$ hydrogen by volume and the recycle stream in the three vessel system has $13 \%$ methane and $62 \%$ hydrogen. Dr. Muradov's experimental setup examines a single-pass reactor process. More hydrogen is produced in the three vessel design than the POx design because combustion takes place in a separate vessel. Direct combustion in the POx system consumes some of the recycled hydrogen, producing water in the reactor product stream.

\subsection{Capital Costs}

The total fixed capital investment includes installation, instrumentation, piping, buildings, electrical, yard improvements, service facilities, land, engineering \& construction, and contingencies. Looking at the fixed capital costs, shown in Table 8 , it can be seen that the partial oxidation system is about $50 \%$ more capital intensive than the three vessel system. This can be explained by the increased operating pressure (2.5 MPa vs. $200 \mathrm{kPa})$ and the air separation unit which is required in the partial oxidation system. In the partial oxidation plant, the reactor, air separation unit, and PSA unit contribute to the majority of the capital costs (greater than 91\%), with the air separation unit accounting for between $40 \%$ and $49 \%$ of the total capital (depending on plant size). In the three vessel system, the PSA unit, compressors, and the reactor account for $94 \%$ of the capital costs with each contributing about a third to the total capital cost. 
Table 8: Total Fixed Capital Investment

\begin{tabular}{|c|c|c|}
\hline & \multicolumn{2}{|c|}{$\begin{array}{c}\text { Total Fixed Capital Investment } \\
\text { (MM\$) }\end{array}$} \\
\hline $\begin{array}{c}\text { Hydrogen Production Rate } \\
\left(\mathrm{Nm}^{3} / \text { day }\right)\end{array}$ & $\begin{array}{c}\text { Partial Oxidation } \\
\text { System }\end{array}$ & $\begin{array}{c}\text { Three Vessel } \\
\text { System }\end{array}$ \\
\hline 0.16 & 42.1 & 21.9 \\
\hline 0.53 & 101.9 & 50.6 \\
\hline 1.58 & 230.1 & 119.4 \\
\hline
\end{tabular}

\subsection{Plant Gate Hydrogen Selling Price}

The plant gate hydrogen selling price is determined at a $15 \%$ after-tax IRR and is shown in Table 9 for varying natural gas costs. Figure 4 shows these results graphically. These hydrogen selling prices are based on a carbon selling price of $\$ 0.30 / \mathrm{kg}$. Predicted hydrogen selling prices are calculated using the base case values in the cash flow spreadsheet and mean hydrogen selling prices are determined using Crystal Ball ${ }^{\circledR}$, which accounts for uncertainty in the analysis variables. As stated in Section 7.2, the cost of natural gas is not a variable in Crystal Ball ${ }^{\circledR}$ and was changed independently of the other variables.

Table 9: Predicted (and Mean) Plant Gate Hydrogen Selling Prices (\$/GJ)

\begin{tabular}{|c|c|c|c|c|c|c|c|}
\hline \multirow[b]{2}{*}{ System } & \multirow[b]{2}{*}{$\begin{array}{l}\text { Plant Size } \\
\left(\mathrm{Nm}^{3} / \text { day }\right)\end{array}$} & & \multicolumn{5}{|c|}{ Natural Gas Cost (\$/GJ) } \\
\hline & & & $\begin{array}{c}\$ 2.89 \\
1998 \text { price }\end{array}$ & $\begin{array}{c}\$ 3.72 \\
2000 \text { price } \\
\text { (base case) }\end{array}$ & $\begin{array}{c}\$ 4.79 \\
10 / 00 \text { price }\end{array}$ & $\begin{array}{l}\$ 5.69 \\
\text { predicted }\end{array}$ & $\begin{array}{c}\$ 6.64 \\
\text { predicted }\end{array}$ \\
\hline & & & \multicolumn{5}{|c|}{ Plant Gate Hydrogen Selling Price (\$/GJ) } \\
\hline $\begin{array}{l}\text { Partial } \\
\text { Oxidation }\end{array}$ & 0.16 & $\begin{array}{r}\text { Predicted } \\
\text { Mean }\end{array}$ & $\begin{array}{c}\$ 21.46 \\
(\$ 24.62)\end{array}$ & $\begin{array}{c}\$ 23.60 \\
(\$ 26.80)\end{array}$ & $\begin{array}{c}\$ 26.38 \\
(\$ 29.57)\end{array}$ & $\begin{array}{c}\$ 28.70 \\
(\$ 31.89)\end{array}$ & $\begin{array}{c}\$ 31.17 \\
(\$ 34.38)\end{array}$ \\
\hline $\begin{array}{l}\text { Partial } \\
\text { Oxidation }\end{array}$ & 0.53 & $\begin{array}{r}\text { Predicted } \\
\text { Mean }\end{array}$ & $\begin{array}{c}\$ 14.61 \\
(\$ 17.37)\end{array}$ & $\begin{array}{c}\$ 16.75 \\
(\$ 19.53)\end{array}$ & $\begin{array}{c}\$ 19.53 \\
(\$ 22.36)\end{array}$ & $\begin{array}{c}\$ 21.85 \\
(\$ 24.65)\end{array}$ & $\begin{array}{c}\$ 24.33 \\
(\$ 27.13)\end{array}$ \\
\hline $\begin{array}{l}\text { Partial } \\
\text { Oxidation }\end{array}$ & 1.58 & $\begin{array}{r}\text { Predicted } \\
\text { Mean }\end{array}$ & $\begin{array}{c}\$ 10.64 \\
(\$ 13.17)\end{array}$ & $\begin{array}{c}\$ 12.78 \\
(\$ 15.37)\end{array}$ & $\begin{array}{c}\$ 15.56 \\
(\$ 18.12)\end{array}$ & $\begin{array}{c}\$ 17.89 \\
(\$ 20.46)\end{array}$ & $\begin{array}{c}\$ 20.36 \\
(\$ 22.93)\end{array}$ \\
\hline $\begin{array}{l}\text { Three } \\
\text { Vessel }\end{array}$ & 0.16 & $\begin{array}{r}\text { Predicted } \\
\text { Mean }\end{array}$ & $\begin{array}{c}\$ 12.79 \\
(\$ 12.98)\end{array}$ & $\begin{array}{c}\$ 14.48 \\
(\$ 14.69)\end{array}$ & $\begin{array}{c}\$ 16.69 \\
(\$ 16.88)\end{array}$ & $\begin{array}{c}\$ 18.54 \\
(\$ 18.72)\end{array}$ & $\begin{array}{c}\$ 20.51 \\
(\$ 20.67)\end{array}$ \\
\hline $\begin{array}{l}\text { Three } \\
\text { Vessel }\end{array}$ & 0.53 & $\begin{array}{r}\text { Predicted } \\
\text { Mean }\end{array}$ & $\begin{array}{c}\$ 8.88 \\
(\$ 8.97)\end{array}$ & $\begin{array}{c}\$ 10.58 \\
(\$ 10.71)\end{array}$ & $\begin{array}{c}\$ 12.79 \\
(\$ 12.90)\end{array}$ & $\begin{array}{c}\$ 14.64 \\
(\$ 14.75)\end{array}$ & $\begin{array}{c}\$ 16.60 \\
(\$ 16.74)\end{array}$ \\
\hline $\begin{array}{l}\text { Three } \\
\text { Vessel }\end{array}$ & 1.58 & $\begin{array}{r}\text { Predicted } \\
\text { Mean }\end{array}$ & $\begin{array}{c}\$ 7.21 \\
(\$ 7.30)\end{array}$ & $\begin{array}{c}\$ 8.91 \\
(\$ 9.00)\end{array}$ & $\begin{array}{c}\$ 11.12 \\
(\$ 11.21)\end{array}$ & $\begin{array}{c}\$ 12.97 \\
(\$ 13.05)\end{array}$ & $\begin{array}{c}\$ 14.93 \\
(\$ 15.04)\end{array}$ \\
\hline
\end{tabular}

The predicted hydrogen selling price for the partial oxidation system is approximately $50 \%$ higher ( $\$ 3.4$ to $\$ 10.7 / \mathrm{GJ}$ ) than the three vessel system, depending on natural gas cost and plant size. This difference can be attributed to the higher capital cost and the greater natural gas requirement of the partial oxidation system per $\mathrm{kg}$ of hydrogen product. In the partial oxidation system, the mean 
Figure 4: Hydrogen Selling Price vs. Natural Gas Cost (15\% after-tax IRR)

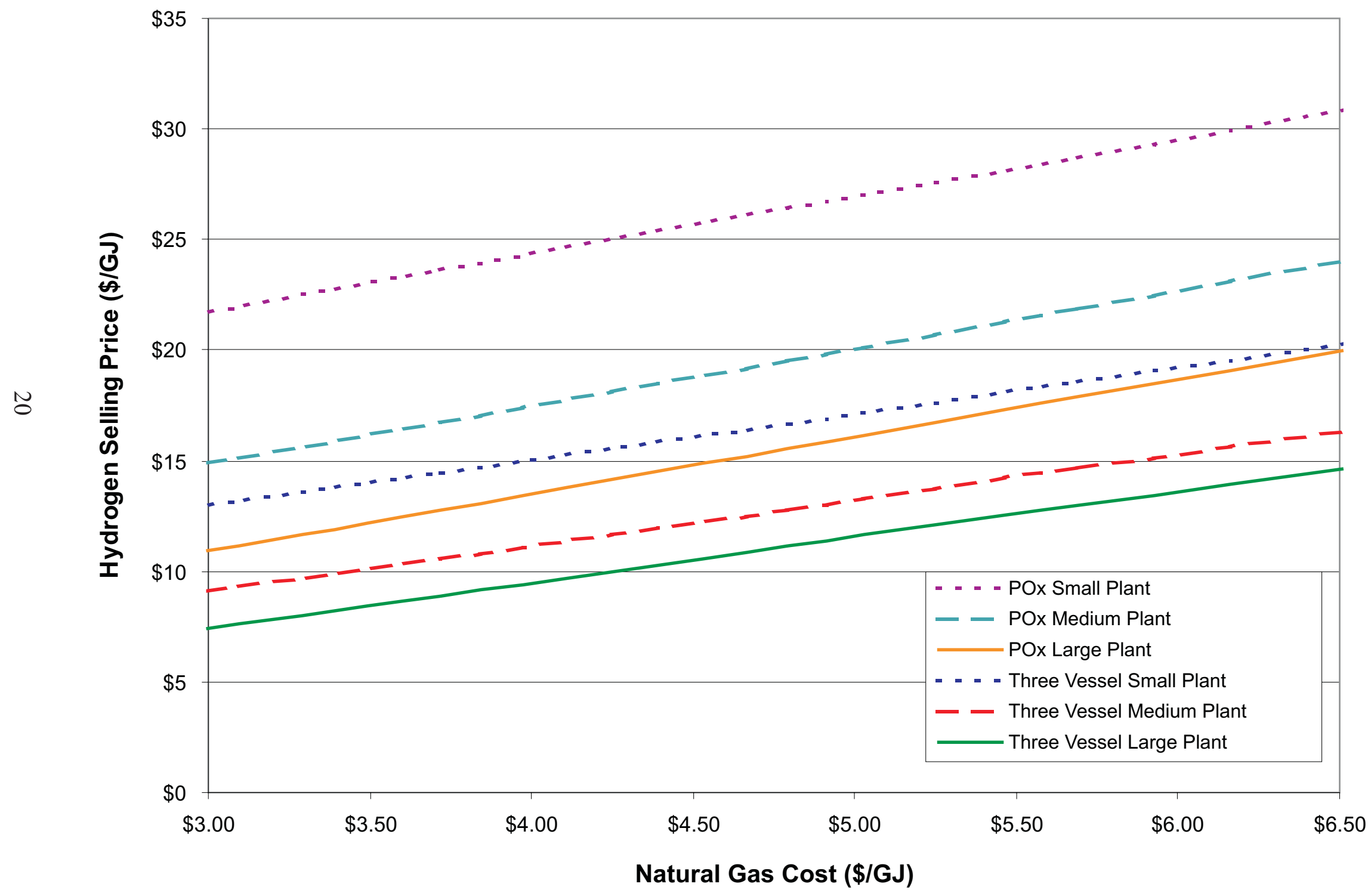


hydrogen selling price was typically $\$ 2.5-\$ 3.2 /$ GJ higher than the predicted hydrogen selling price. For the three vessel system, the mean and predicted prices were much closer $(\$ 0.08-\$ 0.21 / \mathrm{GJ})$, showing greater variability in the partial oxidation hydrogen selling price.

In both systems, the hydrogen selling price decreases with increasing plant size due to economy of scale. Depending on hydrogen plant size, the base case predicted hydrogen selling price varies between $\$ 12.8 / \mathrm{GJ}$ and $\$ 23.6 / \mathrm{GJ}$ for the partial oxidation system and between $\$ 8.9 / \mathrm{GJ}$ and $\$ 14.5 / \mathrm{GJ}$ for the three vessel system. As can be seen in Table 9, the selling price of natural gas has a large effect on hydrogen selling price. A $\$ 2 / \mathrm{GJ}$ increase in the cost of natural gas results in a $\$ 5.1 / \mathrm{GJ}$ increase in the hydrogen selling price for the partial oxidation system and a $\$ 4.1 / \mathrm{GJ}$ increase for the three vessel system.

\subsection{Delivered Price of Hydrogen}

In order to determine the effect of hydrogen storage and transport on the delivered cost of hydrogen, six likely scenarios for hydrogen use were examined. They are presented in Table 10.

Table 10: Hydrogen Storage and Transport Scenarios

\begin{tabular}{|c|l|l|}
\hline Scenario & Hydrogen usage & \multicolumn{1}{|c|}{ Assumptions } \\
\hline 1 & bulk delivery & $16 \mathrm{~km}(10 \mathrm{mi})$ one-way \\
\hline 2 & bulk delivery & $160 \mathrm{~km}(100 \mathrm{mi})$ one-way \\
\hline 3 & bulk delivery & $1,610 \mathrm{~km}(1,000 \mathrm{mi})$ one-way \\
\hline 4 & $\begin{array}{l}\text { on site } \\
\text { consumption }\end{array}$ & 12 hours of storage; no transport \\
\hline 5 & gas station supply & $\begin{array}{l}\text { weekly hydrogen delivery; driving distance of } 160 \mathrm{~km} \text { (100 mi) } \\
\text { round trip; supplying multiple stations along the way; hydrogen use } \\
\text { of } 263 \mathrm{~kg} / \text { day }(580 \text { lb/day }) \text { per gas station }\end{array}$ \\
\hline 6 & pipeline & $\begin{array}{l}3 \mathrm{~km}(1.9 \text { mi) to the nearest pipeline infrastructure; no storage; an } \\
\text { additional } 160 \mathrm{~km}(100 \text { mi }) \text { pipeline for hydrogen delivery to end } \\
\text { user for which the cost is shared by } 5 \text { companies }\end{array}$ \\
\hline
\end{tabular}

In each case, the cheapest delivery and storage method was identified, along with the associated incremental cost that must be added to the production cost to get the total delivered cost of hydrogen. The cost of storing and transporting hydrogen depends on the amount of hydrogen the customer needs and how far their site is from the production facility. The most economical mode of storage and delivery (i.e., liquid, compressed gas, metal hydride, or pipeline delivery) will also vary depending on production rate and distance. For example, while liquid hydrogen delivery is one of the cheapest methods of transporting hydrogen long distances, it requires a large capital investment for a liquefaction facility and there can be significant transfer losses during loading and unloading. This large capital investment at the production site, along with product losses, can make another method of delivery more cost effective. The hydrogen storage and transport costs were determined using a spreadsheet model developed at NREL (Amos 1998). Table 11 shows the additional cost of storing and transporting the hydrogen produced. The costs in this table should be added to the plant gate hydrogen selling price to determine a delivered hydrogen selling price. Overall, for the options studied in this analysis, storage and delivery adds $\$ 0.1$ to $\$ 13 /$ GJ to the plant gate hydrogen selling price. 
Table 11: Additional Costs of Hydrogen Storage and Transportation for Each Option

\begin{tabular}{|c|l|c|c|c|}
\hline Scenario & Storage/Transportation Option & $\begin{array}{c}\text { Small Plant } \\
(\$ / G J)\end{array}$ & $\begin{array}{c}\text { Medium Plant } \\
(\$ / G J)\end{array}$ & $\begin{array}{c}\text { Large Plant } \\
(\$ / G J)\end{array}$ \\
\hline 1 & Gaseous/Pipeline & $\$ 1.47$ & $\$ 2.29$ & $\$ 4.79$ \\
\hline 2 & Gaseous/Pipeline & $\$ 4.29$ & $\$ 9.35$ & $\$ 11.81$ \\
\hline 3 & Liquid/Liquid rail & $\$ 9.16$ & $\$ 10.71$ & $\$ 13.26$ \\
\hline 4 & Gaseous/None & $\$ 1.14$ & $\$ 1.39$ & $\$ 1.75$ \\
\hline 5 & Gaseous/Pipeline & $\$ 1.60$ & $\$ 4.47$ & $\$ 7.58$ \\
\hline 6 & None/Pipeline & $\$ 0.08$ & $\$ 0.20$ & $\$ 0.68$ \\
\hline
\end{tabular}

\subsection{Sensitivity Analysis Results}

The sensitivity analysis shows the influence that each variable has on the results. The assumption variables (described in Section 8.0) are presented here as a percentage of the contribution to variance in the hydrogen selling price. The greater the variance, the greater the contribution of that variable to the change in hydrogen selling price from the predicted value.

\subsubsection{Monte Carlo Results}

For the natural gas cost range examined in this analysis, the following assumption variables contribute the greatest amount of uncertainty to the results: yield of carbon product, operating capacity, carbon selling price, and hydrogen production factor. In the partial oxidation system, the yield of carbon has the greatest amount of uncertainty with a $30 \%-64 \%$ contribution to variance, depending on plant size and natural gas cost. Following the yield of carbon are the operating capacity factor with a 11\%-26\% contribution to variance, hydrogen production factor with a $6 \%-20 \%$ contribution to variance, the air separation unit cost multiplier $(6 \%-16 \%$ contribution), carbon selling price ( $2 \%-5 \%$ contribution), and reactor cost multiplier ( $2 \%-3 \%$ contribution). In the three vessel system, the yield of carbon has a $23 \%-55 \%$ contribution to variance, depending on the plant size and cost of natural gas. The hydrogen production factor has the second greatest effect with a 10-35\% contribution to variance, followed by operating capacity factor (10\%-32\% contribution), and carbon selling price (5\%-12\% contribution). Those with lesser contributions to variance are the PSA cost multiplier ( $2 \%-6 \%$ contribution) and the reactor cost multiplier ( $1 \%-4 \%$ contribution).

\subsubsection{Sensitivity of Hydrogen Selling Price to Carbon Selling Price}

The carbon selling price was a variable in the Crystal Ball ${ }^{\circledR}$ analysis. However, to more closely examine the sensitivity of the base case hydrogen selling price to this variable only, the carbon selling price was changed independently from the other variables. Table 12 shows the sensitivity of the base case hydrogen selling price to the carbon selling price only. A base case carbon selling price of $\$ 0.30 / \mathrm{kg}$ is used in this analysis, however, if the carbon byproduct can not be sold, a $\$ 0 / \mathrm{kg}$ carbon selling price would be assumed. As the carbon selling price increases, the byproduct credit increases, thus reducing the hydrogen selling price to achieve a $15 \%$ IRR. Figure 5 shows the results of this table graphically. If the carbon byproduct can not be sold, the partial oxidation results show an increase of $\$ 8.3 / \mathrm{GJ}$ from the base case hydrogen selling price and the three vessel system results show an increase of $\$ 4.9 / \mathrm{GJ}$ from the base case. 
Table 12: Sensitivity of Plant Gate Hydrogen Selling Price to Carbon Selling Price

\begin{tabular}{|c|c|c|c|c|c|c|}
\hline \multirow{3}{*}{$\begin{array}{l}\text { Carbon } \\
\text { Selling Price } \\
(\$ / \mathrm{kg})\end{array}$} & \multicolumn{3}{|c|}{ Partial Oxidation } & \multicolumn{3}{|c|}{ Three Vessel } \\
\hline & Small Plant & Medium Plant & Large Plant & Small Plant & Medium Plant & Large Plant \\
\hline & \multicolumn{3}{|c|}{$\begin{array}{l}\text { Predicted Plant Gate Hydrogen Selling Price } \\
\qquad(\$ / G J)\end{array}$} & \multicolumn{3}{|c|}{$\begin{array}{l}\text { Predicted Plant Gate Hydrogen Selling Price } \\
\qquad(\$ / G J)\end{array}$} \\
\hline$\$ 0$ & $\$ 31.92$ & $\$ 25.07$ & $\$ 21.11$ & $\$ 19.35$ & $\$ 15.44$ & $\$ 13.78$ \\
\hline$\$ 0.10$ & $\$ 29.14$ & $\$ 22.30$ & $\$ 18.33$ & $\$ 17.73$ & $\$ 13.82$ & $\$ 12.16$ \\
\hline$\$ 0.20$ & $\$ 26.37$ & $\$ 19.52$ & $\$ 15.56$ & $\$ 16.11$ & $\$ 12.20$ & $\$ 10.53$ \\
\hline $\begin{array}{c}\$ 0.30 \\
\text { (Base case) }\end{array}$ & $\$ 23.60$ & $\$ 16.75$ & $\$ 12.78$ & $\$ 14.48$ & $\$ 10.58$ & $\$ 8.91$ \\
\hline$\$ 0.40$ & $\$ 20.83$ & $\$ 13.97$ & $\$ 10.01$ & $\$ 12.86$ & $\$ 8.96$ & $\$ 7.29$ \\
\hline$\$ 0.50$ & $\$ 18.05$ & $\$ 11.20$ & $\$ 7.23$ & $\$ 11.24$ & $\$ 7.33$ & $\$ 5.67$ \\
\hline
\end{tabular}

\subsubsection{Sensitivity of Hydrogen Selling Price to Internal Rate of Return}

Table 13 shows the base case sensitivities of hydrogen selling price to IRR for a $0 \%$ (pre-tax), $10 \%$, $15 \%$, and $20 \%$ after-tax IRR. The $0 \%$ case represents the plant gate hydrogen production cost. The $10 \%$ case is included mostly for illustrative purposes, as it is unlikely that an investor will be willing to accept such a low rate of return on a high risk project. Investors will likely require a $15 \%$ or even a $20 \%$ IRR for novel technologies.

Table 13: Plant Gate Hydrogen Selling Prices for Differing Internal Rates of Return

\begin{tabular}{|l|c|c|c|c|c|}
\hline & & \multicolumn{4}{|c|}{ Internal Rate of Return } \\
\hline System & $\begin{array}{c}\text { Plant Size } \\
\left(\mathrm{Nm}^{3} / \text { day }\right)\end{array}$ & $\begin{array}{c}0 \% \\
\text { pre-tax })\end{array}$ & \multicolumn{2}{|c|}{\begin{tabular}{c}
$10 \%$ \\
Predicted Plant Gate Hydrogen Selling Price (\$/GJ) \\
\hline base case)
\end{tabular}} & $20 \%$ \\
\hline $\begin{array}{l}\text { Partial } \\
\text { oxidation }\end{array}$ & 0.16 & $\$ 6.83$ & $\$ 17.72$ & $\$ 23.60$ & $\$ 30.26$ \\
\hline $\begin{array}{l}\text { Partial } \\
\text { oxidation }\end{array}$ & 0.53 & $\$ 4.70$ & $\$ 12.54$ & $\$ 16.75$ & $\$ 21.45$ \\
\hline $\begin{array}{l}\text { Partial } \\
\text { oxidation }\end{array}$ & 1.58 & $\$ 3.73$ & $\$ 9.63$ & $\$ 12.78$ & $\$ 16.32$ \\
\hline Three vessel & 0.16 & $\$ 6.82$ & $\$ 11.86$ & $\$ 14.48$ & $\$ 17.73$ \\
\hline Three vessel & 0.53 & $\$ 5.38$ & $\$ 8.79$ & $\$ 10.58$ & $\$ 12.83$ \\
\hline Three vessel & 1.58 & $\$ 4.80$ & $\$ 7.50$ & $\$ 8.91$ & $\$ 10.66$ \\
\hline
\end{tabular}

As expected, the internal rate of return has a large effect on the hydrogen selling price. The hydrogen selling price is more sensitive to changes in IRR for the partial oxidation system. A 5\% increase in the IRR, from the base case of $15 \%$, increases the hydrogen selling price by $28 \%$ in the partial 
Figure 5: Hydrogen Selling Price vs. Carbon Selling Price (15\% after-tax IRR)

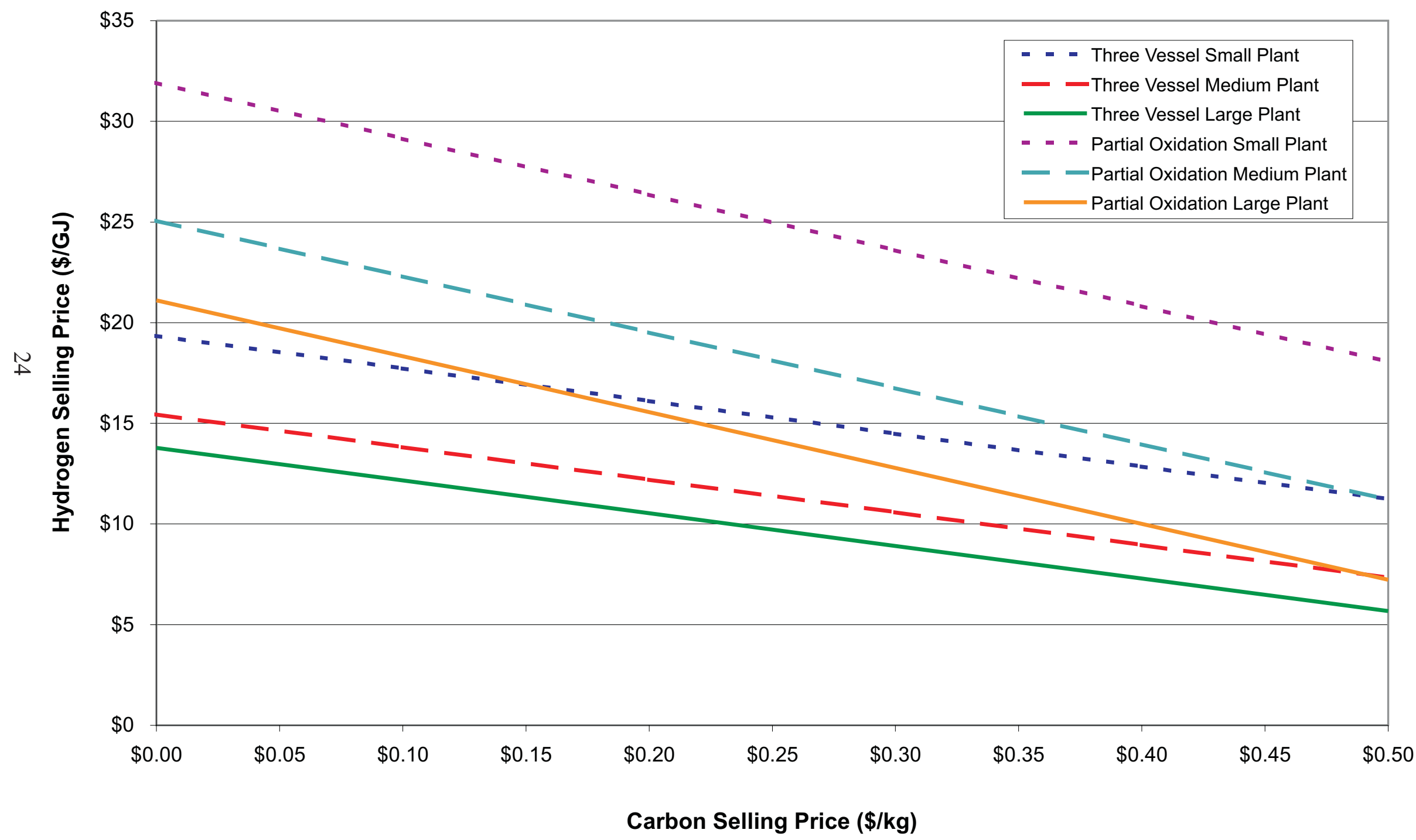


oxidation system and by $20 \%-22 \%$ in the three vessel system. Decreasing the IRR by $5 \%$ from the base case results in a $25 \%$ decrease in the partial oxidation system hydrogen selling price and a $16 \%$ $18 \%$ decrease in the three vessel system.

\subsubsection{Sensitivity Analysis Results of Adding Compression and a Membrane}

As mentioned earlier, the economics of adding a natural gas compressor and of comparing PSA hydrogen purification with membrane separation would be investigated in the sensitivity analyses. Membrane systems are the lowest capital cost alternative for smaller flow rates (less than 0.13 $\mathrm{Nm}^{3} /$ day of product). However, little economy of scale is achieved for larger flow rates, and the process is rarely economical when flow rates are large (greater than $0.66 \mathrm{Nm}^{3} /$ day product) (SRI 1994). The base case assumes natural gas would be received at the hydrogen plant at a desired system pressure. The partial oxidation system runs at high pressure $(2.5 \mathrm{MPa})$ and would require feed compression if this were not the case. The three vessel system is close to atmospheric pressure, and would not require an additional feed compressor.

Table 14 shows the results when using membrane hydrogen purification, a natural gas feed compressor, and both changes. The addition of membrane hydrogen purification results in a $\$ 2.4 / \mathrm{GJ}$ increase for the partial oxidation system and a \$0.3/GJ increase for the three vessel system hydrogen selling prices. Use of a membrane for hydrogen purification causes a greater increase in the hydrogen selling price for the partial oxidation system. This is a result of the higher gas flow rate to the membrane in the POx system. The hydrogen selling prices in Table 14 assume a $15 \%$ after-tax IRR and are based on the base case carbon selling price of $\$ 0.30 / \mathrm{kg}$ and a natural gas price of $\$ 3.72 / \mathrm{GJ}$. Compression of the natural gas adds $\$ 0.5-\$ 1.3 / \mathrm{GJ}$ to the partial oxidation base case selling price, and implementing both changes results in a \$3.0-\$3.8/GJ increase in the hydrogen selling price. As stated earlier, the three vessel system does not require compression.

Table 14: Base Case with a Membrane and/or a Natural Gas Compressor

\begin{tabular}{|l|c|c|c|c|c|}
\hline & & $\begin{array}{c}\text { Base Case } \\
\text { (PSA and no feed } \\
\text { comp.) }\end{array}$ & Membrane & $\begin{array}{c}\text { Natural Gas } \\
\text { Compressor }\end{array}$ & $\begin{array}{c}\text { Both NG } \\
\text { Compressor } \\
\text { \& Membrane }\end{array}$ \\
\hline System & $\begin{array}{c}\text { Plant Size } \\
\left(\mathrm{Nm}^{3} / \text { day) }\right.\end{array}$ & \multicolumn{2}{|c|}{ Predicted Plant Gate Hydrogen Selling Price (\$/GJ) } \\
\hline Partial oxidation & 0.16 & $\$ 23.60$ & $\$ 26.03$ & $\$ 24.92$ & $\$ 27.37$ \\
\hline Partial oxidation & 0.53 & $\$ 16.75$ & $\$ 19.18$ & $\$ 17.56$ & $\$ 19.99$ \\
\hline Partial oxidation & 1.58 & $\$ 12.78$ & $\$ 15.21$ & $\$ 13.30$ & $\$ 15.73$ \\
\hline Three vessel & 0.16 & $\$ 14.48$ & $\$ 14.77$ & N/A & N/A \\
\hline Three vessel & 0.53 & $\$ 10.58$ & $\$ 10.86$ & N/A & N/A \\
\hline Three vessel & 1.58 & $\$ 8.91$ & $\$ 9.20$ & N/A & N/A \\
\hline
\end{tabular}

\subsection{Greenhouse Gas Emissions}

To accurately compare the greenhouse gas emissions from these two process with those from SMR, a life-cycle approach was taken and emissions from the hydrogen production plant, upstream natural gas production and distribution, and avoided carbon black production were included. Figure 6 shows the three systems and the resulting greenhouse gas emissions from each source. Overall, production 
Figure 6: Greenhouse Gas Emissions from Hydrogen Production via Steam Methane Reforming and Thermocatalytic Decomposition of Natural Gas

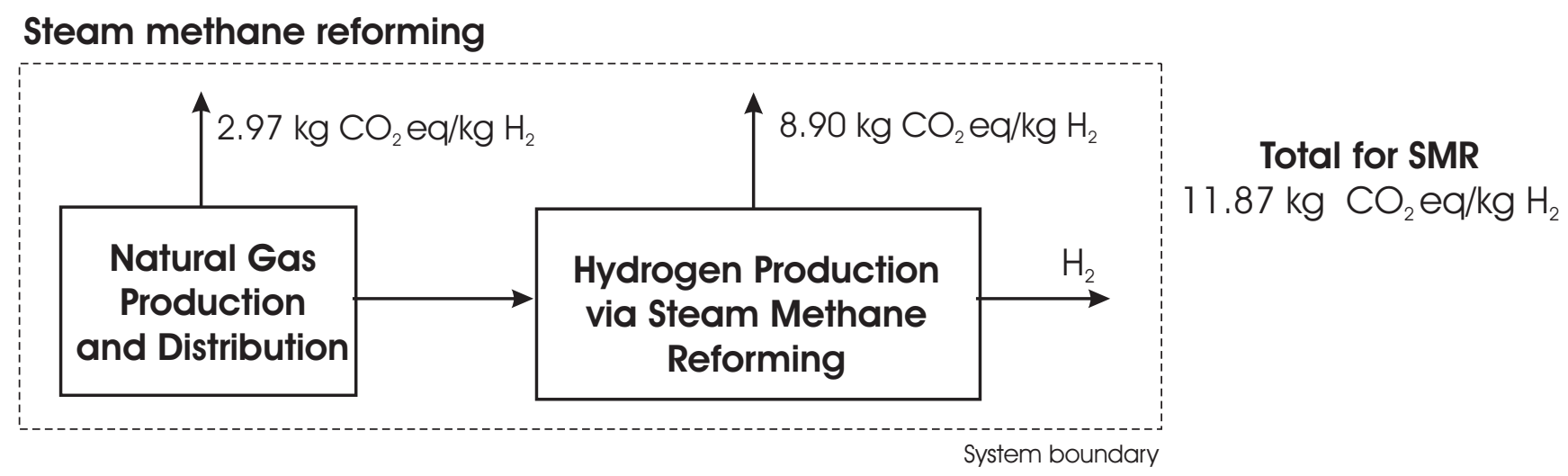

TCD-Partial oxidation

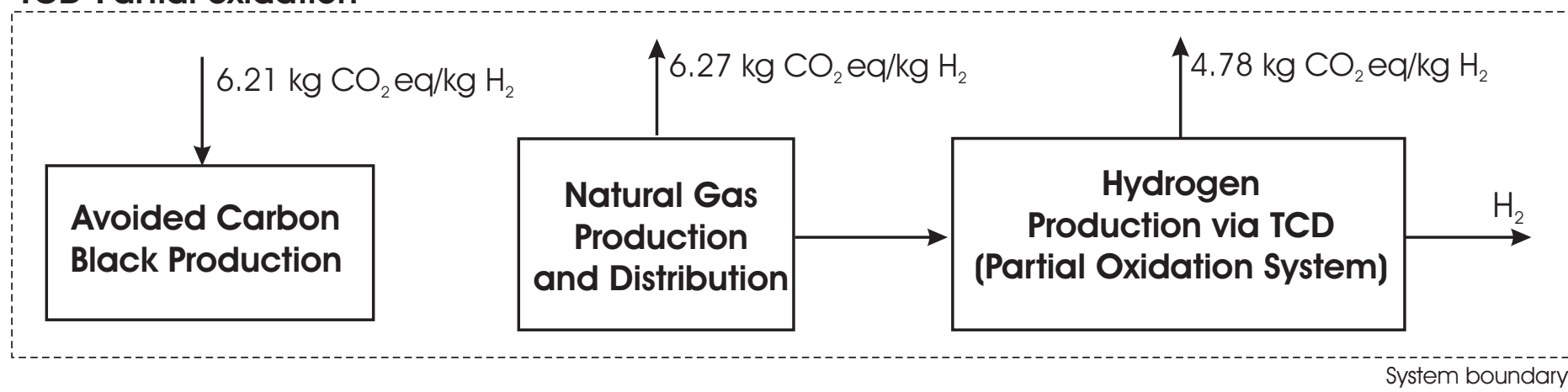

Total for POx $4.84 \mathrm{~kg} \mathrm{CO}$ eq/ $/ \mathrm{kg} \mathrm{H}_{2}$

TCD-Three vessel

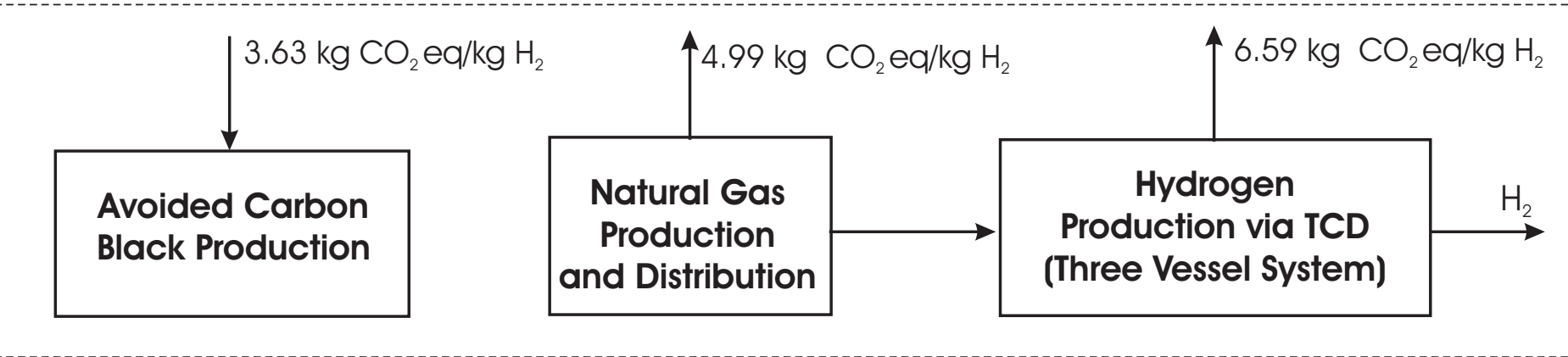

Total for three vessel $7.95 \mathrm{~kg} \mathrm{CO}$ eq $/ \mathrm{kg} \mathrm{H}_{2}$ 
of hydrogen via thermocatalytic decomposition results in reduced greenhouse gas emissions per kilogram of hydrogen produced, when compared with SMR. The greenhouse gas emissions are measured in terms of $\mathrm{CO}_{2}$-equivalent $\left(\mathrm{CO}_{2}\right.$-eq. $)$, where methane's greenhouse gas impact is 21 times that of $\mathrm{CO}_{2}$ and nitrous oxide's $\left(\mathrm{N}_{2} \mathrm{O}\right)$ is 310 times that of $\mathrm{CO}_{2}$ (Houghton et al 1996). The net greenhouse gas emissions of hydrogen production via SMR are $11.9 \mathrm{~kg} \mathrm{CO}_{2}$-eq./ $/ \mathrm{kg} \mathrm{H}_{2}$, compared with $4.8 \mathrm{~kg} \mathrm{CO}_{2}$-eq. $/ \mathrm{kg} \mathrm{H}_{2}$ in the partial oxidation system, or a $59 \%$ reduction from SMR, and 8.0 $\mathrm{kg} \mathrm{CO}$-eq./ $/ \mathrm{kg} \mathrm{H}_{2}$ in the three vessel system, or a 33\% reduction from SMR. The emissions from SMR were taken from a previous NREL study, Life Cycle Assessment of Hydrogen Production via Natural Gas Reforming (Spath and Mann 2000b).

For SMR, the plant operation alone emits $8.9 \mathrm{~kg} \mathrm{CO}$-eq./kg hydrogen produced (Spath and Mann 2000b). The operating emissions in the partial oxidation plant result from combustion of the recycle gas slipstream. During plant operation, this system emits $4.8 \mathrm{~kg} \mathrm{CO}_{2}$-eq. $/ \mathrm{kg}$ of hydrogen produced. The three vessel plant produces carbon dioxide emissions from combustion of three sources: the fuel natural gas, the fluidized bed heater offgas, and the recycle gas slipstream. During plant operation, these sources produce a total of $6.6 \mathrm{~kg} \mathrm{CO}_{2}$-eq. $/ \mathrm{kg}$ hydrogen, however, the combustion of the recycle gas slipstream only accounts for 5 vol\% of this total amount.

Where SMR theoretically produces four moles of hydrogen for every mole of methane, the stoichiometry of the thermocatalytic decomposition of methane allows only two moles of hydrogen per mole of methane as shown in the following reactions.

$$
\begin{array}{ll}
\text { SMR: } & \mathrm{CH}_{4}+\mathrm{H}_{2} \mathrm{O} \leftrightarrow \mathrm{CO}+3 \mathrm{H}_{2} \\
\text { net rxn: } & \frac{\mathrm{CO}+\mathrm{H}_{2} \mathrm{O} \leftrightarrow \mathrm{CO}_{2}+\mathrm{H}_{2-}}{\mathrm{CH}_{4}+2 \mathrm{H}_{2} \mathrm{O} \leftrightarrow \mathrm{CO}_{2}}+4 \mathrm{H}_{2} \\
\text { TCD: } & \mathrm{CH}_{4} \leftrightarrow \mathrm{C}_{\text {(solid) }}+2 \mathrm{H}_{2}
\end{array}
$$

In SMR, the hydrogen in the methane and in the water contribute to the production of hydrogen, whereas TCD relies solely on the hydrogen contained in the methane to produce hydrogen. Because thermocatalytic decomposition of methane requires more natural gas per kilogram of hydrogen than SMR, the upstream greenhouse gases from natural gas production and distribution are higher for the partial oxidation and three vessel systems (see Figure 6) than SMR. For SMR, the greenhouse gases emitted during natural gas production and distribution are $3.0 \mathrm{~kg} \mathrm{CO}_{2}$-eq. $/ \mathrm{kg}$ of hydrogen produced. For the partial oxidation and three vessel systems, emissions from natural gas production and distribution were calculated using the natural gas requirements in Table 6 . The results show $6.3 \mathrm{~kg}$ $\mathrm{CO}_{2}$-eq./ $\mathrm{kg} \mathrm{H}$ are produced from natural gas production and distribution in the partial oxidation system and $5.0 \mathrm{~kg} \mathrm{CO}_{2}$-eq. $/ \mathrm{kg}$ of hydrogen are produced in the three vessel system.

Finally, the emissions from a conventional carbon black process must be subtracted to obtain the overall greenhouse gas emissions from each thermocatalytic decomposition system. These are the avoided emissions from producing carbon via the partial oxidation or three vessel route. The greenhouse gas emissions for carbon black were obtained from Tools for Environmental Analysis and Management $\left(\mathrm{TEAM}^{\circledR}\right)$, which is a life cycle assessment software package by Ecobalance. The software database, DEAM, contains cradle-to-grave greenhouse gas emissions for carbon black production via crude oil. About $95 \%$ of the total U.S. production of carbon black uses a heavy aromatic feedstock from petroleum refining in the furnace black process (SRI 1999). The credit from the carbon produced in the partial oxidation system and three vessel system is $6.2 \mathrm{~kg} \mathrm{CO}_{2}-$ eq. $/ \mathrm{kg} \mathrm{H}_{2}$ and $3.6 \mathrm{~kg} \mathrm{CO}$-eq. $/ \mathrm{kg} \mathrm{H}_{2}$, respectively. 


\subsection{Future Work}

Hydrogen is typically produced via SMR because it is often the most economical method. If a credit system were implemented for avoided greenhouse gas emissions, production of hydrogen using thermocatalytic decomposition would be closer to the hydrogen selling price from SMR. A future analysis could examine the effect of credits for avoided greenhouse gas emissions on the hydrogen selling price for these two systems and compare these systems with hydrogen produced from SMR.

\subsection{Research Recommendations}

Data used for this analysis comes from Dr. Muradov's single pass experimental reactor setup. It is not known how the carbon activity will be affected by recycling the carbon. Decreased activity is expected when a recycle loop is added, and some amount of fresh carbon may be needed to maintain high conversion of the natural gas. Lab data showing how the carbon activity changes over time during the decomposition reaction will be helpful in determining whether some fresh carbon is necessary in the reactor feed. Another area for further examination is the quality of the carbon product. This will allow a more accurate determination of the carbon selling price.

The results of the sensitivity analysis showed variables with the greatest amount of uncertainty in the analysis. The sensitivity analysis produced the following variables related to research: yield of carbon, hydrogen production factor, and carbon selling price (which depends on carbon quality). These variables will have a larger effect on the economics of this process, and should be the primary areas of research focus. 


\subsection{References}

Amos, W.A. (1998). Costs of Storing and Transporting Hydrogen. National Renewable Energy Laboratory. Golden, CO TP-570-25106.

Chemical Engineering. (1992, 1995, 1999, 2000). Current Business Indicators: Hourly earnings index, chemical \& allied products.

Chemical Marketing Reporter. (2001). Price quote of carbon black, fast extruding (N550). January.

Chemical Week. (2001). Market and economics for Carbon Black. 31 January 2001, pp. 26.

Cooper, C.D.; Alley, F.C. (1994). Air Pollution Control A Design Approach, $2^{\text {nd }}$ Ed. Waveland Press, Inc. Prospect Heights, IL, pp. 127-145.

EIA. (2001). Table 23. Average Price of Natural Gas Sold to Industrial Consumers by State. Energy Information Administration's Natural Gas Monthly, January 2001.

Frank, W.B.; Haupin, W.E.; Dawless, D.A.; Wei, M.W.; Calhoun, K.J.; Bonney, T.B. (2001). ALUMINUM - Production. Ullmann's Encyclopedia of Industrial Chemistry. Wiley-VCH Verlag GmbH, Weinheim, Germany.

Garrett, D.E. (1989). Chemical Engineering Economics. Van Nostrand Reinhold, New York, NY, pp. 29, 288, 299.

Gary, J.H.; Handwerk, G.E. (1994). Petroleum Refining Technology and Economics, $3^{\text {rd }}$ Ed. Marcel Dekker, Inc. New York, NY, pp. 85-88

Hammond, D.G.; Parrish, M.R.; Citarella, V.A. (1996). Fluid Coking: A Competitive Option for Heavy Feed Processing. Exxon Research and Engineering Company. Presented at the 1996 NPRA Annual Meeting, San Antonio, TX. March 17-19, 1996.

Houghton, J.T.; Meira Filho, L.G.; Callander, B.A.; Harris, N.; Kattenberg, A.; Maskell, K., eds. (1996). Climate Change 1995. The Science of Climate Change. Published for the Intergovernmental Panel on Climate Change. New York: Cambridge University Press.

ICARUS Reference $2^{\text {nd }}$ Ed. (1997). ICARUS Corporation, Rockville, MD, pp. 14-7.

Kirk-Othmer. (1992). Kirk-Othmer Encyclopedia of Chemical Technology. John Wiley and Sons, Inc. Carbon, Vol. 4, pp. 960-961, 989-991, 1015-1031.

Lacson, J.G. (1999). CEH Product Review: Natural Gas. Chemical Economics Handbook. SRI International. Menlo Park, CA. Volume 4. Section 229.2000.

Massenzio, S.F.; Meyers, R.A. (1984). Exxon Fluid Coking and Flexicoking Processes for synfuels upgrading applications. Handbook of Synfuels Technology. McGraw-Hill Book Company, NY, NY, pp. 6-3 through 6-18.

Muradov, N.Z. (2000 \& 2001). Personal correspondence. Florida Solar Energy Center, Cocoa, FL. 
Muradov, N.Z. (2000). Thermocatalytic $\mathrm{CO}_{2}$-free Production of Hydrogen from Hydrocarbon Fuels. Proceedings of the 2000 Hydrogen Program Review. San Ramon, CA, 9-11 May 2000 .

Perry, R.H.; Green, D.W. (1997). Perry's Chemical Engineers' Handbook, $7^{\text {th }}$ Ed. McGraw Hill, NY, NY, pp 20-15.

Peters, M.S.; Timmerhaus, K.D. (1991). Plant Design and Economics for Chemical Engineers. McGraw-Hill, Inc, pp. 169, 183.

Pietruszkiewicz, J.; Milkavich, R.; Booras, G.; Thomas, G.; Doss, H. (September 1988). An Evaluation of Integrated-Gasification-Combined-Cycle and Pulverized-Coal-Fired Steam Plants. Volume 1: Base Case Studies. Prepared by Bechtel Group, Inc. for EPRI. Final Report number AP-5950.

Pohlenz, J.B.; Stine, L.O. (1962). Retention of Hydrogen Values in Petroleum Refining. Presented at the Annual Meeting of the National Petroleum Refiners Association, San Antonio, TX, 2-4 April 1962.

Shelton, W. (1999). Personal correspondence. EG\&G Technical Services of West Virginia. Morgantown, WV.

Smith, B. (6 February 2001). Personal correspondence. Technical Information Center, Air Products, Lehigh Valley, PA.

Spath, P.L.; Lane, J.M.; Mann, M.K.; Amos, W.A. (2000a). Update of Hydrogen from Biomass Determination of the Delivered Cost of Hydrogen. National Renewable Energy Laboratory. Golden, CO. Milestone report.

Spath, P.L.; Mann, M.K. (2000b). Life Cycle Assessment of Hydrogen Production via Natural Gas Steam Reforming. National Renewable Energy Laboratory. Golden, CO. TP-570-27637.

SRI International. (December 1999). Chemical Economics Handbook. Activated Carbon, pp. 731.2000D-H.

SRI International. (February 1999). Chemical Economics Handbook. Carbon Black, pp. 731.3000D-M.

SRI International. (May 1997). Chemical Economics Handbook. Graphite, pp. 731.5000A-U.

SRI International. (1995). PEP Yearbook International. Volume 1E. United States. Process Economics Program. Menlo Park, CA.

SRI International. (February 1994). Options for Refinery Hydrogen. Report 212. Process Economics Program. Menlo Park, CA

Steinberg, M. (5 February 2001). Personal correspondence. Brookhaven National Laboratory, Upton, NY.

Steinberg, M. (1998). Production of Hydrogen and Methanol from Natural Gas with Reduced $\mathrm{CO}_{2}$ Emission. International Journal of Hydrogen Energy, Vol. 23, No. 6, pp. 419-425. 
Steinberg, M. (1995). Prospective Technologies for Hydrogen Production. NATO ASI Ser. E, 295. Hydrogen Energy System, pp 31-44.

Turton, R.; Bailie, R.C.; Whiting, W.B.; Shaeiwitz, J.A. (1998). Analysis, Synthesis, and Design of Chemical Processes. Prentice Hall, Upper Saddle River, NJ, pp. 490.

Ullmann's Encyclopedia of Industrial Chemistry. (1986). 4th Edition, Weinheim (Federal Republic of Germany): VCH. Vol. A5, pp. 140-152.

U.S. EPA. (February 1998). Compilation of Air Pollutant Emission Factors, Fifth edition. United States Environmental Protection Agency. AP-42. Vol. 1, chapter 12.1; Primary Aluminum Production. Ann Arbor, MI.

Winter, J. (1997). Personal correspondence. Technologist for Texaco at the Montebello Technology Center. Montebello, CA. 


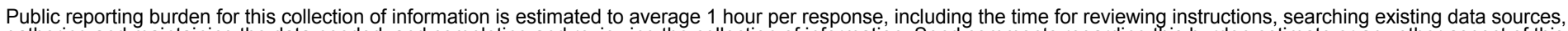

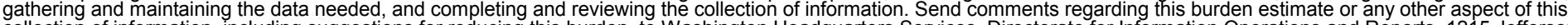

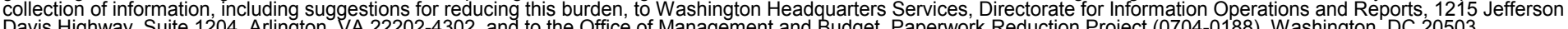

Davis Highway, Suite 1204, Arlington, VA 22202-4302, and to the Office of Management and Budget, Paperwork Reduction Project (0704-0188), Washington, DC 20503.
1. AGENCY USE ONLY (Leave blank)
2. REPORT DATE
December 2001
3. REPORT TYPE AND DATES COVERED
Technical Report

\section{TITLE AND SUBTITLE \\ Technoeconomic Analysis of the Thermocatalytic Decomposition of Natural Gas}

5. FUNDING NUMBERS

6. $\mathrm{AUTHOR}(\mathrm{S})$

Janice M. Lane, Pamela L. Spath

7. PERFORMING ORGANIZATION NAME(S) AND ADDRESS(ES)

National Renewable Energy Laboratory

1617 Cole Blvd.

HY024041

Golden, CO 80401-3393

8. PERFORMING ORGANIZATION

REPORT NUMBER

NREL/TP-510-31351

9. SPONSORING/MONITORING AGENCY NAME(S) AND ADDRESS(ES)

10. SPONSORING/MONITORING AGENCY REPORT NUMBER

11. SUPPLEMENTARY NOTES

12a. DISTRIBUTION/AVAILABILITY STATEMENT

National Technical Information Service

12b. DISTRIBUTION CODE

U.S. Department of Commerce

5285 Port Royal Road

Springfield, VA 22161

13. ABSTRACT (Maximum 200 words)

NREL conducted economic analysis examining two process designs for producing hydrogen from thermocatalytic decomposition based on research by Dr. Nazim Muradov of FSEC.

14. SUBJECT TERMS

Hydrogen; thermocatalytic decomposition; pressure swing adsorption; FSEC, natural gas
15. NUMBER OF PAGES

16. PRICE CODE

20. LIMITATION OF ABSTRACT
19. SECURITY CLASSIFICATION OF ABSTRACT

Unclassified
UL 